\title{
Chemistry and particle size distribution of respirable coal dust in underground mines in Central Eastern Europe
}

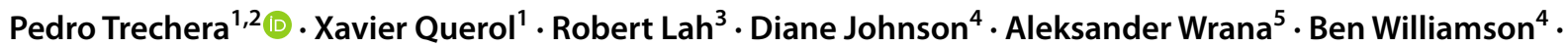 \\ Teresa Moreno ${ }^{1}$
}

Received: 24 March 2021 / Accepted: 4 January 2022

(c) The Author(s) 2022

\begin{abstract}
Despite international efforts to limit worker exposure to coal dust, it continues to impact the health of thousands of miners across Europe. Airborne coal dust has been studied to improve risk models and its control to protect workers. Particle size distribution analyses shows that using spraying systems to suppress airborne dusts can reduce particulate matter concentrations and that coals with higher ash yields produce finer dust. There are marked chemical differences between parent coals and relatively coarse deposited dusts (up to $500 \mu \mathrm{m}, \mathrm{DD}_{500}$ ). Enrichments in $\mathrm{Ca}, \mathrm{K}, \mathrm{Ba}, \mathrm{Se}, \mathrm{Pb}, \mathrm{Cr}, \mathrm{Mo}, \mathrm{Ni}$ and especially $\mathrm{As}, \mathrm{Sn}, \mathrm{Cu}, \mathrm{Zn}$ and $\mathrm{Sb}$ in the finest respirable dust fractions could originate from: (i) mechanical machinery wear; (ii) variations in coal mineralogy; (iii) coal fly ash used in shotcrete, and carbonates used to reduce the risk of explosions. Unusual enrichments in $\mathrm{Ca}$ in mine dusts are attributed to the use of such concrete, and elevated $\mathrm{K}$ to raised levels of phyllosilicate mineral matter. Sulphur concentrations are higher in the parent coal than in the $\mathrm{DD}_{500}$, probably due to relatively lower levels of organic matter. Mass concentrations of all elements observed in this study remained below occupational exposure limits.
\end{abstract}

Keywords Coal dust $\cdot$ Deposited dust $\cdot$ Respirable dust $\cdot$ Particle size distribution $\cdot$ Dust chemistry $\cdot \mathrm{PM}_{10}$ coal dust exposure

\section{Introduction}

Around $66 \%$ and $57 \%$ of current European coal production and demand respectively is restricted to central-eastern countries such as Poland, Germany, Czech Republic and Ukraine (BP 2020). In this region, existing coal reserves comprise

Pedro Trechera

pedro.trechera@idaea.csic.es

1 Instituto de Diagnóstico Ambiental Y Estudios del Agua, Consejo Superior de Investigaciones Científicas, (IDAEACSIC), C/Jordi Girona 18-26, 08034 Barcelona, Spain

2 Department of Natural Resources and Environment, Industrial and TIC Engineering (EMIT-UPC), 08242 Manresa, Spain

3 Premogovnik Velenje d.d, Partizanskacesta 78, 3320 Velenje, Slovenia

4 Camborne School of Mines, University of Exeter, Penryn, Cornwall TR10 9FE, UK

5 Department of Extraction Technology and Mining Support, Central Mining Institute (GIG), 40-166 Katowice, PlacGwarkow 1, Poland a total of 53,383 Mt of anthracite and bituminous reserves and 56,945 Mt of sub-bituminous and lignite reserves, which together account for $82 \%$ of European Union and around $11 \%$ of worldwide coal reserves (BP 2020). Given the continued importance of this industry in eastern Europe, and although coal mining activity in Europe has been steadily decreasing during the last few years (Jonek-Kowalska 2018), the environmental impact of coal mining on workers' health remains a matter of concern (Więckol-Ryk et al. 2018; Song et al. 2020). Of particular relevance is the amount and chemistry of the coal dust produced in underground coal mines. Coal dust is a chemically heterogeneous mixture of carbonaceous matter, with a variable mineral content (e.g. quartz, sulphates and sulphides), and has distinctive major (Fe, $\mathrm{Si}$, $\mathrm{S}$ ) and trace element ( $\mathrm{As}, \mathrm{Pb}, \mathrm{Cr}, \mathrm{Mn}, \mathrm{U})$ signatures which may be linked to classic coal worker diseases such as pneumoconiosis (CWP) or progressive massive fibrosis (PMF) (Dalal et al. 1995; Liu et al. 2005; Cohen et al. 2008; Li et al. 2013; Caballero-Gallardo and Olivero-Verbel 2016; Fang et al. 2020; Pedroso-Fidelis et al. 2020; Jin et al. 2021). In recent years, the use of improved technologies has generally increased mine output but has also, in some cases, 
produced higher concentrations of dust (Perret et al. 2017; Johann-Essex et al. 2017; Leonard et al. 2020; Fan and Liu 2021). This may have been a factor in the resurgence of coal mining-related respiratory diseases in some mines (e.g. Fan et al., 2018; Wu et al., 2019). For this reason, dust monitoring control during the handling of different mining technologies requires extensive investigation, including information on the physicochemical characteristics of the deeply inhalable (particle size below $10 \mu \mathrm{m}$ ) and respirable fractions (particle size below $4 \mu \mathrm{m}$ and $2.5 \mu \mathrm{m}$ ), both of which could be a key factor in the prevention of coal dust problems in mining, such as diverse authors are contributing (Zhang et al. 2020; Szkudlarek and Janas 2021; Jiang and Luo 2021; Liu et al. 2021; Reed et al. 2021).

In this study, as part of the European ROCD project (Reducing risks from Occupational exposure to Coal Dust), we focussed on the chemical characterisation of coarse $(<500 \mu \mathrm{m})$ and respirable $(<4$ and $<2.5 \mu \mathrm{m})$ coal dusts and their parent coals from underground mines in CentralEastern Europe. This included determining the nature and origins of chemical fractionation of major and trace elements between different size fractions of dust. In addition, samples of mine airborne particulate matter below $10 \mu \mathrm{m}\left(\mathrm{PM}_{10}\right)$, emitted during different coal mining activities, were also

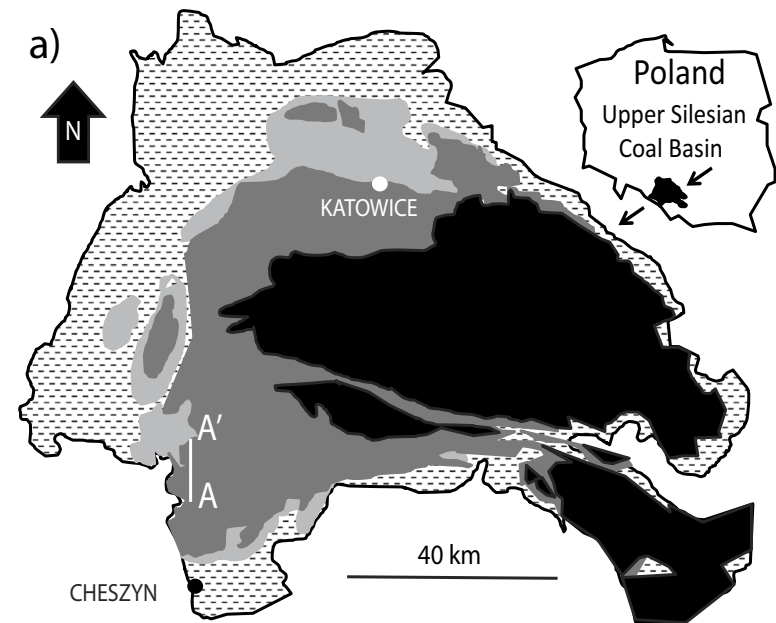

Bottom unit (Mississippian) Lower, Middle and Upper Coal Bearing Units
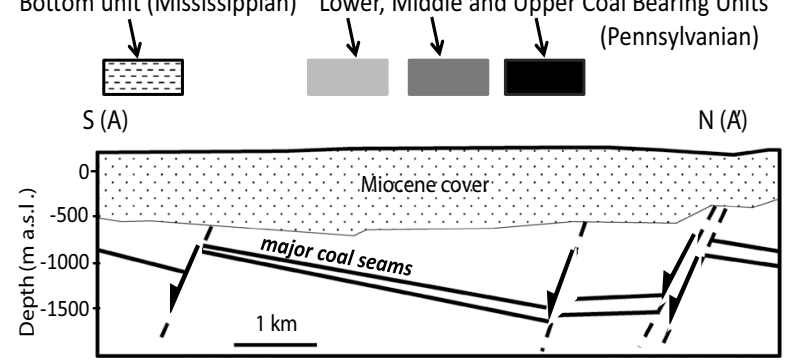

Fig. 1 a Upper: Geological map of the Upper Silesian Coal Basin in Southern Poland. A-A' indicates the location of the geological cross section (lower figure). Modified from Kędzior (2019). b Upper: obtained and analysed to evaluate possible chemical differences and the efficiency of ventilation and air suppression systems.

\section{Geological settings}

A total of 16 underground coal mines have been sampled for this study (Table S1 in Supplementary Material), all of them located in two coal mining areas of Central-Eastern Europe: Upper Silesian Coal Basin (USCB, 15 mines) and Velenje Coal Basin (VCB, 1 mine).

\subsection{Upper silesian coal basin}

The USCB, which is one of the major coal basins in Europe, covers an area of around $7500 \mathrm{~km}^{2}\left(5800 \mathrm{~km}^{2}\right.$ in Poland and $1600 \mathrm{~km}^{2}$ in the Czech Republic, Fig. 1a); only $30 \%$ of its exploitable coal resources have been worked (Kotarba 2001; Kusiak et al. 2006; Stępniewska et al. 2014; Vaněk et al. 2017). It is a basin of polygenetic origin: the lower part (Namurian A) consists of an Upper Carboniferous coal-bearing lithostratigraphic sequence deposited in a

b)
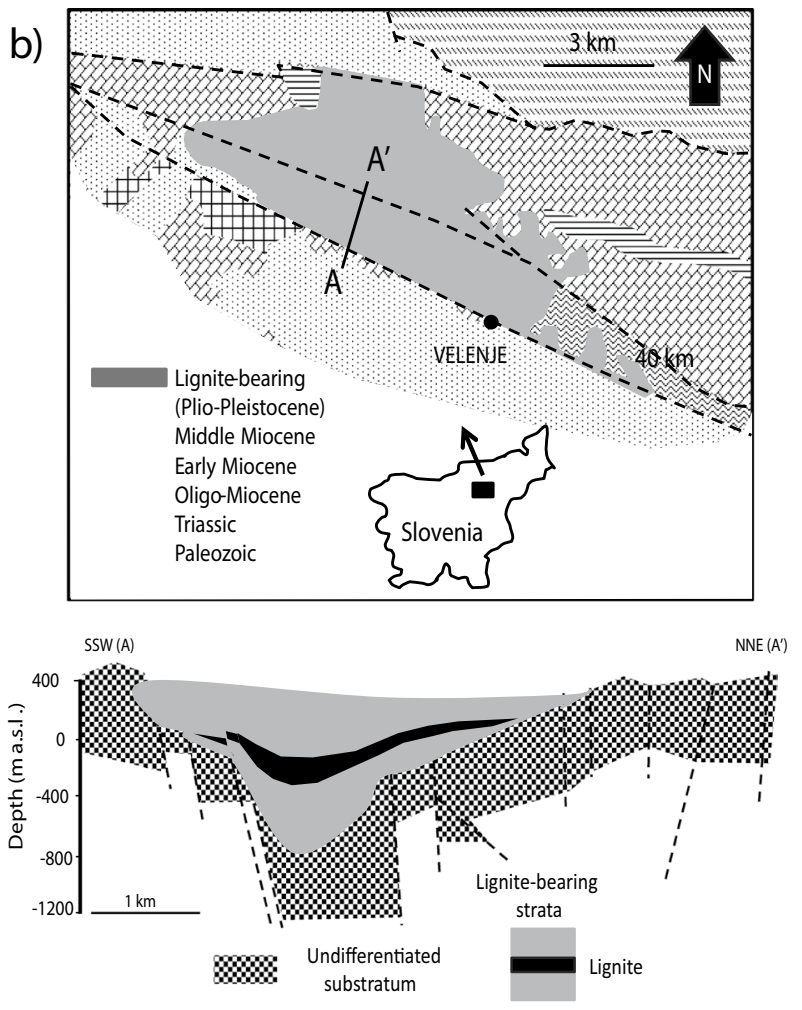

Geological map of the Velenje Coal Basin area. Lower: Schematic geological cross-section of the Velenje Basin. For location of A - B cross-section see upper map. Adapted from Brezigar et al. (1987) 


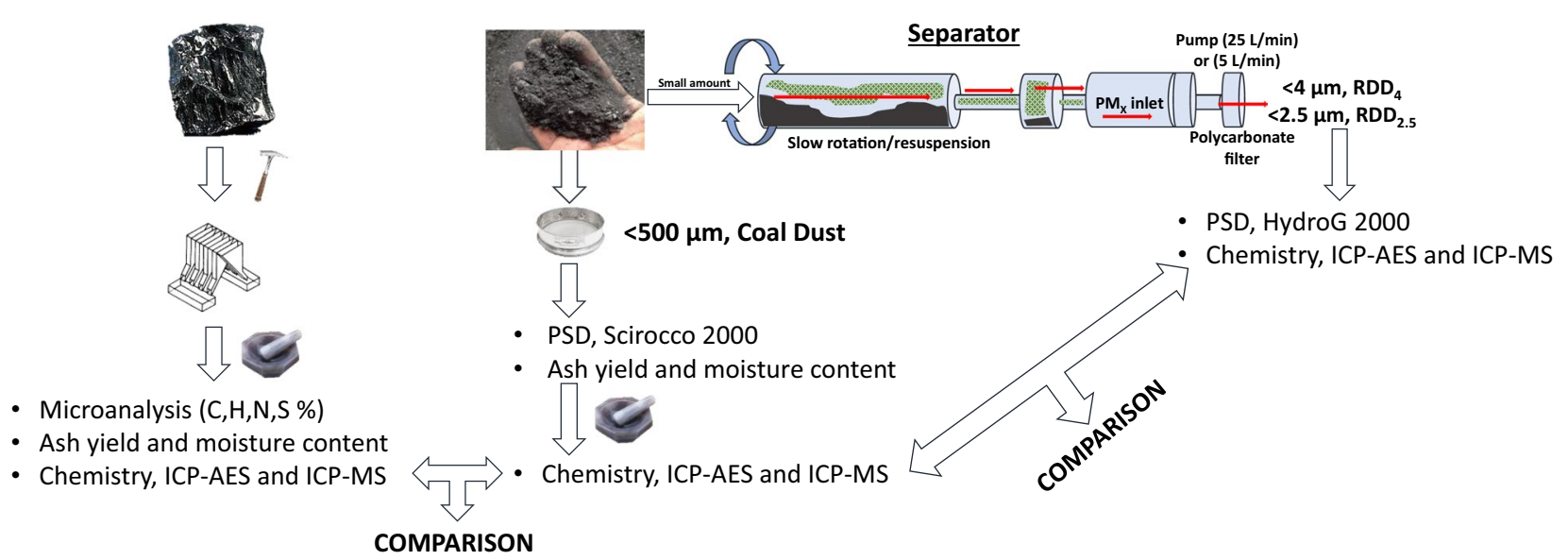

Fig. 2 Schematic of the sampling procedures used for parent coal, deposited dust and separation of the respirable deposited dust, and subsequent analyses

paralic environment, whereas the upper part (Namurian B to Wesphalian D) is of purely continental origin (Kotas and Porzycki 1984; Kotas et al. 1994; Kotarba 2001; Kusiak et al. 2006).

The USCB hosts a wide range of coal types, from lowrank (sub-bituminous), high- to low-volatile rank (bituminous) to high-rank (anthracite) (Kotarba 2001; Kusiak et al. 2006; Kędzior 2009). Only the bituminous and sub-bituminous coals are mined and used in power stations (EPA 1995; Kedzior 2015). On average, USCB coals contain 0.9\%-2\% sulphur, have an ash yield of $11 \%-16 \%$ and calorific values ranging from 29 to $32 \mathrm{MJ} / \mathrm{kg}$ (EPA 1995).

\subsection{Velenje coal basin}

The VCB is located in NE Slovenia, at the SE end of the Alps, $70 \mathrm{~km}$ NE of Ljubljana (Fig. 1b). The coal has an average calorific value of $8-13 \mathrm{MJ} / \mathrm{kg}$, an ash yield of $5 \%-40 \%$ $\mathrm{db}$, a moisture content of $15 \%-45 \%$ and sulphur content of $0.5 \%-2 \% \mathrm{db}$ (Markič and Sachsenhofer 2010). The lignitebearing Pliocene to Early Quaternary sediments accumulated in a $12 \mathrm{~km}$ long and $4 \mathrm{~km}$ wide WNW-ESE trending, fault bounded, depression. The mainly clastic basin fill is up to $1000 \mathrm{~m}$ thick, and contains a lenticular $10 \mathrm{~km}$ long, $3 \mathrm{~km}$ wide and up to $160 \mathrm{~m}$ thick lignite seam of Pliocene age (Brezigar 1987; Markic and Sachsenhofer 1997; Kędzior 2019).

\section{Methodology}

\subsection{Mine sampling}

A total of 91 deposited dust (DD) samples were collected manually inside the mines using two different methods.
The most common method involved using a brush and a hermetic-sterilised plastic bag. Additionally, some coal DD samples were collected, using a plastic tray left in a specific workplace within the underground mine for 24-48 h, before being stored in a sterilised container. These two different coal dust collection methods offered the opportunity to compare relatively "aged" dust (which accumulated over an unknown time period, collected using a brush) with fresh DD on trays. In addition, given the likelihood that dustgenerating activities carried out in the underground mines is related to the coal seam being worked, 16 rock samples of 'parent' coals were collected (Table S2 in Supplementary Material). See sampling details in Tables S3, S4 and S5 in Supplementary Material. Parent coals refer to coal samples extracted from the coal seam exploited during the DD sampling collection. They were used to examine any possible change in chemical composition compared to the DD samples.

\subsection{Sample analysis}

\subsubsection{Sample pre-treatment}

Figure 2 provides an overview of the analytical procedures undertaken: (i) DD samples were sieved to $<500 \mu \mathrm{m}\left(\mathrm{DD}_{500}\right)$ for the determination of particle size distribution (PSD), proximate, ultimate and geochemical composition; (ii) a small (riffle-split) portion (100 g) of these DD samples (as received) was size separated using a special $\mathrm{PM}_{4}$ or $\mathrm{PM}_{2.5}$ separator/collection device to produce a respirable DD fraction (RDD, dust finer than $4 \mu \mathrm{m}$ or $2.5 \mu \mathrm{m}, \mathrm{RDD}_{4}$ or $\mathrm{RDD}_{2.5}$, respectively); (iii) parent coal rock samples were homogenised by crushing (using a hammer), mixing, and milling (using a Mortar Agatha Grinder RM 200 device in an automatic mode), prior to proximate and geochemical analysis. 
In detail, to obtain the $\mathrm{RDD}_{4}$ or $\mathrm{RDD}_{2.5}$ samples, a separator was used following the protocols previously detailed by Amato et al. (2009a, b) and Moreno et al. (2019). The sieved coal $\mathrm{DD}_{500}$ samples were placed within the separator (which comprises a methacrylate chamber which has a volume of $4697 \mathrm{~cm}^{2}$ by $17 \mathrm{~cm}$ of diameter) and subjected to mild resuspension as a result of slow rotation $(1.5 \mathrm{rpm})$. The resuspended particles were sampled by drawing air, at a rate of 5 or $25 \mathrm{~L} / \mathrm{min}$ for $\mathrm{RDD}_{2.5}$ and $\mathrm{RDD}_{4}$ respectively, through a size-selective inlet head which deposits $\mathrm{PM}_{4}$ or $\mathrm{PM}_{2.5}$ on to a $0.60 \mu \mathrm{m}$ pore size, $47 \mathrm{~mm}$ diameter polycarbonate filter. This type of filter is strong enough, does not contaminate the sample, and allows for a relatively easy extraction from its surface. After that, the RDD samples were ready for chemical analysis.

\subsubsection{Particle size distribution}

The PSD of DD and RDD samples was determined using a Malvern Mastersizer device. For DD samples, a Scirocco 2000 unit was coupled to this device in order to disperse and separate the particulate in an air stream ready for laser diffraction size determination. For RDD samples (with very low sample volumes) PSD was obtained using a wet (water-polyphosphate RDD suspension) HydroG 2000 coupled unit to verify their $\mathrm{RDD}_{4}$ size separation (Sperazza et al. 2004).

\subsubsection{Proximate, ultimate and chemical characterization}

Coal sample proximate and ultimate analyses were done following ISO and ASTM procedures (ISO-589, 1981, ISO1171, 1976, ISO-562, 1974, ASTM D-3286, D-3302 M, D3174-12), with moisture (M) and ash yields (HTA) obtained at 105 and $750{ }^{\circ} \mathrm{C}$.

Prior to geochemical analysis, coal, $\mathrm{DD}_{500}$ and RDD samples were $\mathrm{HF}-\mathrm{HNO}_{3}-\mathrm{HClO}_{4}$ acid digested following the method of Querol et al. $(1997,1992)$ to retain potentially volatile elements, such as As and Se. The resulting sample solutions were analysed for major and trace elements by Inductively-Coupled Plasma Atomic-Emission Spectrometry for major elements (ICP-AES, Iris Advantage Radial ER/S device from Thermo Jarrell-Ash) and Inductively-Coupled Plasma Mass Spectrometry for trace elements (ICP-MS, X-SERIES II Thermo Fisher Scientific, Bremen, Germany). International reference materials SARM19 and NIST SRM 1633b, and blanks were treated in the same way. After thirteen analyses of the above reference materials, analytical errors and relative standard deviations (RSDVs) were included in Table S6 in Supplementary Material.

\subsection{4 $\mathrm{PM}_{10}$ measurements}

The use of most electrical PM monitoring and collection devices in underground coal mines is not possible due to the risk of coal dust explosion. For this reason, only ATEXcertified instruments are permitted. In this study, a TECORA-CIP10 thoracic PM sampler (CIP10), designed for operation in explosive environments, was used to determine $\mathrm{PM}_{10}$ ambient concentrations during specific coal mining activities. The sampler, which operates at a flow rate of 10 $\mathrm{L} / \mathrm{min}$, has a $\mathrm{PM}_{10}$-selective inlet that retains the $>10 \mu \mathrm{m}$ $\mathrm{PM}$ on an impaction surface and collects the $\mathrm{PM}_{10}$ onto a polyurethane foam.

The lack of amount sample retained in the filter foam makes sometimes impossible for their digestions, for this reason, some filter collection keeping always same conditions were occasionally combined. The mass of airborne $\mathrm{PM}_{10}$ per volume of air is calculated from the weight of the two fractions divided by the volume sampled. The CIP10 samplers were mainly operated for a period of 80-135 min, or, in a few cases, for 60-160 min.

The $\mathrm{PM}_{10}$ fractions retained in the polyurethane foam were subject to acid digestion using a mixture of $\mathrm{HF}, \mathrm{HNO}_{3}$ and $\mathrm{HClO}_{4}$, following the method previously discussed in the Sect. 3.2.3. The whole foam was digested. However, in this case $10 \mathrm{~mL}$ of $\mathrm{HNO}_{3}$ was used in the first step, instead of $2.5 \mathrm{~mL}$, and then all of the $\mathrm{HNO}_{3}$ was evaporated off to eliminate the organic excess part of the foam (polyurethane) and avoid combustion in the second acid digestion step. Finally, all sample digested was recovered in the final of the second step ready for ICP-MS and ICP-AES analysis. Blank foams were digested using the same protocol and their contained concentrations of different elements then subtracted from the measured concentrations in the samples.

\section{Results and discussion}

\subsection{Particle size distribution}

A total of 91 coal DD samples from both coal basins and 2 Dust samples from VCB warehouse (Malta and Calplex, dust samples used in some places of the underground mine for security, preventing ignitions or collapses) were analysed for their PSD, moisture content (\%M, air dried, ad) and ash yield (\%HTA, dry bases, db) (Tables S7 and S8 in Supplementary Material). Mean contents of the $<500\left(\mathrm{DD}_{500}\right),<10$ $\left(\mathrm{DD}_{10}\right),<4\left(\mathrm{DD}_{4}\right)$, and $<2.5 \mu \mathrm{m}\left(\mathrm{DD}_{2.5}\right)$ in $\mathrm{DD}$ from both coal basins reached $98.0 \%, 17.0 \%, 6.0 \%$ and $3.3 \%$ volume (\%v), respectively, for VCB samples, and 98\%, 35\%, 16\% and $10 \% \mathrm{v}$, respectively, for USCB. Thus, the proportions of $\mathrm{DD}_{10}, \mathrm{DD}_{4}$ and $\mathrm{DD}_{2.5}$ in the DD samples from USCB were more than double those from the VCB. In contrast, mean 
moisture contents were higher in the VCB samples (12\% ad VCB vs. $1.0 \%$ ad USCB), and ash yield means were similar (36\% for VCB and $38 \%$ for USCB).

The markedly higher moisture and lower $\mathrm{DD}_{10}, \mathrm{DD}_{4}$ and $\mathrm{DD}_{2.5}$ proportions in the $\mathrm{VCB} \mathrm{DD}_{500}$ are probably due to wetting of airborne and deposited coal dust in the underground mines and not to differences in coal rank. If that is the case, then it is likely that it has reduced markedly the proportion of finer particle sizes by agglomeration of particles. Thus, in the VCB underground mine, PSD analysis of very low moisture dust samples yield $\mathrm{DD}_{2.5}$ fractions reaching up to $23 \% \mathrm{DD}_{500}$. The efficiency of wetting $\mathrm{DD}$ in reducing coal mine worker exposure to dust, as well as in preventing coal dust explosions, is very well documented (Woskoboenko 1988; Küçük et al. 2003; Kuai et al. 2012; Yuan et al. 2014; Ajrash et al. 2017; Azam et al. 2019; Hu et al. 2021; Zhang et al. 2021). Küçük et al. (2003) and Yuan et al. (2014) found that a decrease in the dust fraction below $<125 \mu \mathrm{m}$ can be achieved by increasing the moisture content of deposited coal dust. These studies emphasise the importance of keeping a minimum moisture content in DD to prevent explosions. There is a balance to be found, however, as maintaining relatively low ambient humidity levels in underground mines provides a more comfortable working environment (Sunkpal et al. 2017) which improves workplace productivity.

When moisture contents of $\mathrm{DD}_{500}$ and then $\mathrm{DD}_{10}, \mathrm{DD}_{4}$ and $\mathrm{DD}_{2.5}$ were determined independently for each of the two basins, some significant correlations were found for samples from the VCB mine (Eqs. (1)-(9)); no such correlation was found in the USCB samples. This is probably because the moisture contents are very low $(0.2 \%$ ad to $5.4 \% \mathrm{ad}$ ) in USCB, compared to VCB (5.5\% ad to $27 \% \mathrm{ad})$ samples. On the other hand, systematic correlations between size fraction and HTA yields were only significant in the USCB DD samples, where a wider range of HTA yields of $\mathrm{DD}_{500}$ were obtained (8.2\% ad to $79 \%$ ad in USCB, compared with $19 \%$ ad to $47 \%$ ad in $\mathrm{VCB}$ ).

Another plausible explanation to account for the negative correlation between moisture content and fine $\mathrm{DD}_{500}$ fractions, different to the abatement of the fine dust fraction caused by the wetting of dust, is that the moisture content in $\mathrm{DD}_{500}$ from VCB increases with the coal content of the dust. An elevated coal matrix content in dust can yield to coarser dust, as well as higher moisture content (because this a lignite and accordingly moisture increases with the increase of the organic content), without the need of increasing moisture content by wetting DD. However, we do not believe this is the case because of the lack of correlation between ash yields and the fine fractions of $\mathrm{DD}_{500}$ in VCB. Thus, we point to the different degrees of wetting of the $\mathrm{DD}_{500}$ samples to account for the different concentrations of the fine fractions. On the other hand, this wetting may be hiding possible correlations between ash yields and fine fraction sizes, as found for the low moisture dust from USCB.

In the case of the DD collected at the VCB mine, these included fresh DD deposited on a plastic tray (24-48 h collection time, 9 samples) and aged DD brushed from surfaces (9 samples). There was therefore a total of 18 of the 21 samples analysed ( 3 samples were considered outliers due to problems in their collection or store). Results for the different methods of collection are shown below to evaluate possible differences in the PSD of DD samples collected with the two methods.

Velenje coal basin samples

Fresh DD samples $(n=9 / 10)$

$$
\begin{aligned}
& \mathrm{DD}_{2.5}(\% \mathrm{v})=-0.285 \% M, \mathrm{ad}+7.328 R^{2}=0.746 \\
& \mathrm{DD}_{4}(\% \mathrm{v})=-0.407 \% M, \mathrm{ad}+11.887 R^{2}=0.677 \\
& \mathrm{DD}_{10}(\% \mathrm{v})=-1.087 \% M, \mathrm{ad}+32.201 R^{2}=0.667
\end{aligned}
$$

Aged DD samples $(n=9 / 11)$

$\mathrm{DD}_{2.5}(\% \mathrm{v})=-0.229 \% M, \mathrm{ad}+6.170 R^{2}=0.779$

$\mathrm{DD}_{4}(\% \mathrm{v})=-0.329 \% M, \mathrm{ad}+10.176 R^{2}=0.707$

$\mathrm{DD}_{10}(\% \mathrm{v})=-0.905 \% M, \mathrm{ad}+28.276 R^{2}=0.639$

All DD samples $(n=18 / 21)$

$\mathrm{DD}_{2.5}(\% \mathrm{v})=-0.250 \% M, \mathrm{ad}+6.680 R^{2}=0.754$

$\mathrm{DD}_{4}(\% \mathrm{v})=-0.359 \% \mathrm{M}, \mathrm{ad}+10.948 R^{2}=0.688$

$\mathrm{DD}_{10}(\% \mathrm{v})=-0.975 \% M, \mathrm{ad}+30.030 R^{2}=0.648$

Very similar results were obtained for the two types of DD samples, showing that the DD sampling protocols collect dust with similar PSDs. Also, when the two warehouse samples are added, the correlation between moisture and particle size increases, presumably because warehouse samples (Malta and Calplex) have much lower moisture contents and much higher HTA yields $(0.4 \%$ ad and $0.6 \%$ ad moisture and 98 and $62 \%$ db HTA), and therefore contain more fine dust.

Upper silesian coal basin samples

Marcel DD samples $(n=8 / 10)$

$\mathrm{DD}_{2.5}(\% \mathrm{v})=0.495 \% \mathrm{HTA}, \mathrm{db}-9.075 R^{2}=0.958$ 


$$
\begin{aligned}
& \mathrm{DD}_{4}(\% \mathrm{v})=0.664 \% \mathrm{HTA}, \mathrm{db}-10.416 R^{2}=0.977 \\
& \mathrm{DD}_{10}(\% \mathrm{v})=0.949 \% \mathrm{HTA}, \mathrm{db}-10.502 R^{2}=0.982
\end{aligned}
$$

Bielszowice DD samples $(n=16 / 16)$

$$
\begin{aligned}
& \mathrm{DD}_{2.5}(\% \mathrm{v})=0.422 \% \mathrm{HTA}, \mathrm{db}-3.131 R^{2}=0.856 \\
& \mathrm{DD}_{4}(\% \mathrm{v})=0.567 \% \mathrm{HTA}, \mathrm{db}-1.901 R^{2}=0.810 \\
& \mathrm{DD}_{10}(\% \mathrm{v})=0.856 \% \mathrm{HTA}, \mathrm{db}+3.810 R^{2}=0.681
\end{aligned}
$$

Pniowek DD samples $(n=14 / 15)$

$$
\begin{aligned}
& \mathrm{DD}_{2.5}(\% \mathrm{v})=0.214 \% \mathrm{HTA}, \mathrm{db}+2.504 R^{2}=0.780 \\
& \mathrm{DD}_{4}(\% \mathrm{v})=0.2 .83 \% \mathrm{HTA}, \mathrm{db}+7.578 R^{2}=0.673 \\
& \mathrm{DD}_{10}(\% \mathrm{v})=0.409 \% \mathrm{HTA}, \mathrm{db}+30.305 R^{2}=0.335
\end{aligned}
$$$$
\text { Rest USCB DD samples }(n=23 / 28)
$$$$
\mathrm{DD}_{2.5}(\% \mathrm{v})=0.230 \% \mathrm{HTA}, \mathrm{db}+1.287 R^{2}=0.776
$$$$
\mathrm{DD}_{4}(\% \mathrm{v})=0.378 \% \mathrm{HTA}, \mathrm{db}+4.196 R^{2}=0.728
$$$$
\mathrm{DD}_{10}(\% \mathrm{v})=0.494 \% \mathrm{HTA}, \mathrm{db}+20.191 R^{2}=0.433
$$

All USCB DD samples $(n=61 / 69)$

$$
\begin{aligned}
& \mathrm{DD}_{2.5}(\% \mathrm{v})=0.310 \% \mathrm{HTA}, \mathrm{db}-0.610 R^{2}=0.759 \\
& \mathrm{DD}_{4}(\% \mathrm{v})=0.431 \% \mathrm{HTA}, \mathrm{db}+1.529 R^{2}=0.733 \\
& \mathrm{DD}_{10}(\% \mathrm{v})=0.670 \% \mathrm{HTA}, \mathrm{db}+12.07 R^{2}=0.500
\end{aligned}
$$

A correlation was found between the proportions of finer fractions in $\mathrm{DD}_{500}$ and the ash yield for the USCB samples. An increase in the HTA yield was positively correlated with levels of the finer PSD, which is most obvious for the $\mathrm{DD}_{2.5}$ size fraction (8 samples of a total of 69 have not been considered in these calculations being outliers in data from each of the mines) (Eqs. (10)-(24)). This fact makes sense because the coal matrix (organic fraction) breaks to give coarser dust particles than clay, quartz and other mineral species, which increases the ash yields. Furthermore, the very low moisture contents of these $\mathrm{DD}_{500}$ samples allow finding these ash and high loads of fine DD fractions (Palmer et al. 1990; Jiang and Sheng 2018; Trechera et al. 2020). Another possible reason for the correlation between particle size and ash content in the USCB, not related to moisture content, could be that, given the high ranks of these coals, moisture is associated with the inorganic part, namely mineral matter (Jiang and Sheng 2018). However, this seems not to be the case here because of the lack of correlation between moisture and ash yields in most mines from the USCB, and the negative correlations found in two of them (Marcel and Bobrek-Piekary, Table 2). It is important also to highlight that when considering samples from all the mines from the USCB, the marked positive correlation is still evident $\left(R^{2}=0.76,0.73\right.$ and 0.50 for $\mathrm{DD}_{2.5}, \mathrm{DD}_{4}$ and $\mathrm{DD}_{10}$, Eqs. (22)-(24)), suggesting a regional similarity across the entire USCB coal basin, independently of the 15 individual mines sampled.

A multilinear regression analysis was performed both between moisture and ash contents for each mine separately (in USCB), and by method of collection (in VCB). No correlations were observed showing that moisture content is not provided by the coal samples (with the exception of Marcel and Bobrek-Piekary mines, previously commented).

\subsection{Geochemical characterisation}

\subsubsection{Velenje coal basin samples}

The concentrations of different elements in the coal sample generally lie within the range for worldwide coals presented by Ketris and Yudovich (2009) (Table S9), with a few minor exceptions (Tables S10, S11 and S12) such as for P (higher by a factor of 1.2), $\mathrm{Zn}$ (1.4), U (1.6) and Mn (1.7).

\subsubsection{Deposited dust samples $\left(\mathrm{DD}_{500}\right)$}

Figure $3 \mathrm{a}$ and $\mathrm{b}$ show a comparison between major and trace element concentrations in coal dust and parent coal samples. Most of the major elements show higher $(2 \times$ or more $)$ concentrations in the coal dust, with the exception of $S$ which is very similar. This could relate to either: (i) a higher content in mineral matter, with elements such as $\mathrm{Al}, \mathrm{Na}, \mathrm{P}$ or $\mathrm{K}$ coming from the coal gangue; (ii) the mixing of coal dust with coal fly ash (Malta fly ash is commonly used in the mines as backfill, and Calplex, a carbonate 'rock dust,' is used for fire hazard reduction), that is chemically enriched in $\mathrm{Al}, \mathrm{Mg}, \mathrm{Fe}, \mathrm{Ca}, \mathrm{Na}, \mathrm{P}$, and $\mathrm{K}$ compared to coal (Table S13 in Supplementary Material); (iii) machine wear, especially for elements such as $\mathrm{Fe}$ and $\mathrm{Mg}$.

With regards to trace elements, again most of them are enriched in the coal dust compared with parent coal samples by $2 \times$ or more, except for Mo and Sr. The trace elements $\mathrm{Sn}, \mathrm{Se}, \mathrm{Ni}, \mathrm{Zr}$ and $\mathrm{Sb}$ show the highest relative enrichments $(>5 \mathrm{x})$, that may be due to contamination from machinery (belts, extractors, drills etc.) in the underground mine. Another potential contaminant is again fly ash (Malta), 


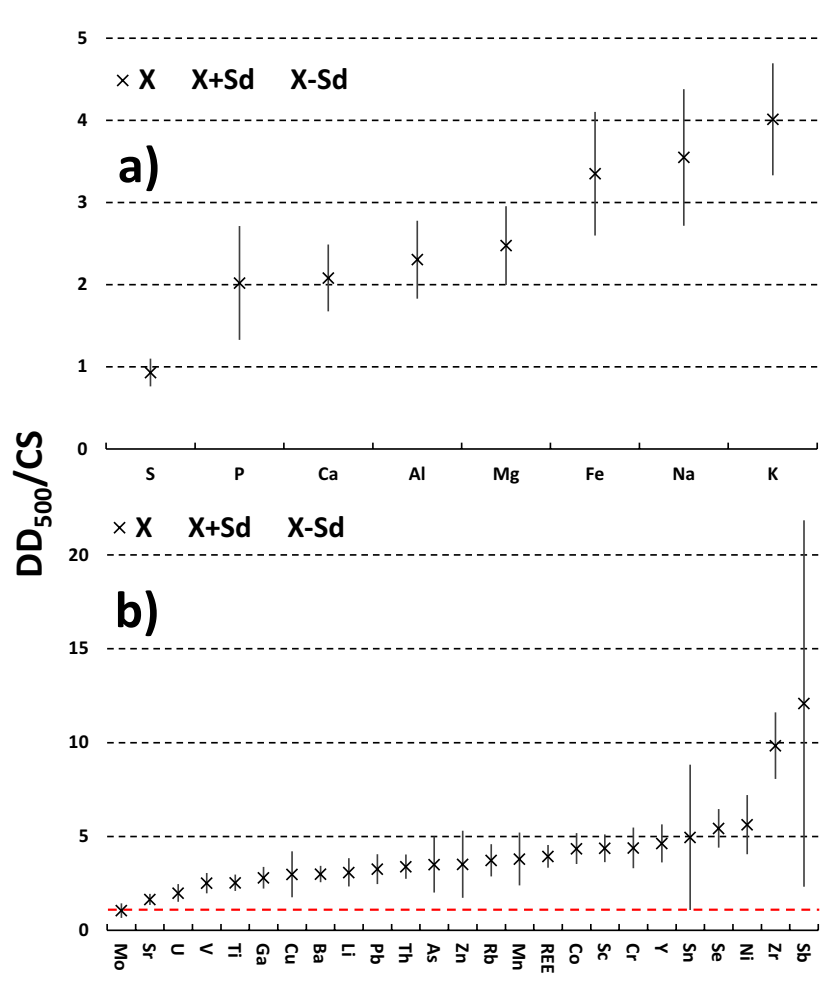

Fig. 3 Average deposited dust/parent coal elemental ratios for all dust fractions and standard deviation for the major (a) and trace (b) elements in the Velenje Coal Basin samples. Dashed red line represents ratio $=1$. Average deposited dust/parent coal ratios from the different methods of collection ("fresh" plastic tray and "aged" mine

especially in trace elements such as $\mathrm{Cr}, \mathrm{Y}, \mathrm{Ni}, \mathrm{Se}$ and $\mathrm{Zr}$ (Table S14).

Figure $3 \mathrm{c}$ and $\mathrm{d}$ compare the trace element contents of $\mathrm{DD}_{500}$ versus those in the parent coal for samples obtained using different collection methods: on plastic trays (fresh) or for longer term (aged) samples deposited onto mine surfaces and collected using a brush. Major elements, and the majority of the trace elements, do not show any appreciable difference according to the coal dust collection method. In the exceptional case of $\mathrm{Sb}$ (Fig. 3d), one might speculate that this could relate to the brushing collection method which may have picked up more brake-contaminated dust on the floor of the mine than that obtained from the collection plastic tray placed $1.5 \mathrm{~m}$ above ground level.

Finally, there are large variations in the elemental concentrations of some $\mathrm{DD}_{500}$ samples. This could be related to the types of mining activities carried out in the specific areas where sampling was carried out. Samples collected from the longwall k.-95/A-conveyor transfer point and longwall k.-95/B-conveyor transfer point present lower $\mathrm{DD}_{500}$ concentrations compared with DD samples from other locations. The sample ROCD_PV_002_4, collected from the longwall k.-95/A-conveyor transfer point, has the lowest element concentrations. This is probably because, in these zones, mining
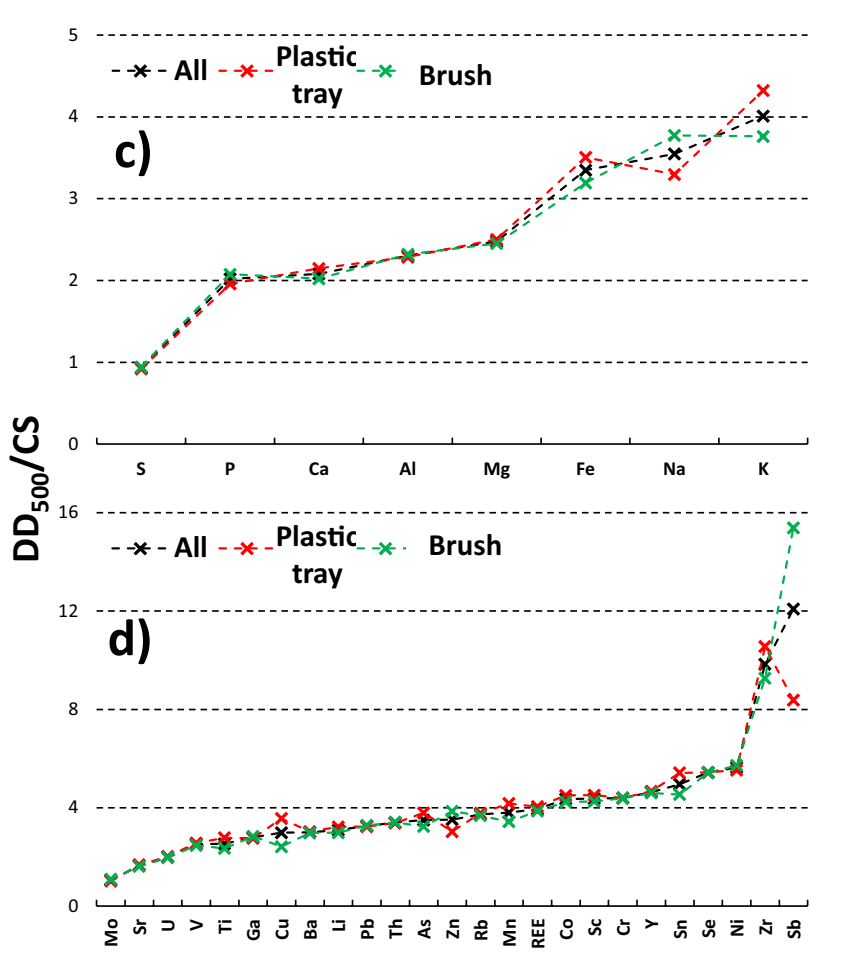

surface deposits collected with a brush) for the major (c) and trace (d) elements in the Velenje Coal Basin. In black, average ratios from all deposited dust coal samples. In red, average ratios from all the "fresh" deposited dust. In green, average ratios from all the "aged" deposited dust

activity is less intense, and for this reason the levels of most elements (except $\mathrm{Sb}$ and $\mathrm{U}$ ) decrease.

\subsubsection{Respirable deposited dust $\left(\mathrm{RDD}_{4}\right.$ and $\left.\mathrm{RDD}_{2.5}\right)$ samples}

The successful separation of the respirable fractions from the deposited coal dust $\left(\mathrm{RDD}_{4}\right.$ and $\left.\mathrm{RDD}_{2.5}\right)$, using our particle size separator device, is demonstrated by the size distributions plotted on Figure S1 and shown in Table S15 in Supplementary Material. Concentrations of major and trace elements (Tables S13 and S14 in Supplementary Material) in these respirable $\left(\mathrm{RDD}_{4}\right.$ and $\left.\mathrm{RDD}_{2.5}\right)$ samples, and the specific $\mathrm{RDD}_{4} / \mathrm{DD}_{500}$ ratios are shown in Fig. 4a, where major and trace elements (especially $\mathrm{Ba}, \mathrm{Se}, \mathrm{Zn}, \mathrm{Pb}, \mathrm{As}, \mathrm{Sn}, \mathrm{Cu}$ and $\mathrm{Sb}$ ) are shown to be typically enriched in the finer dust fraction (ratios $\mathrm{RDD}_{4} / \mathrm{DD}_{500}$ 1.2-1.4: Fig. 4a).

Further fractionation into the $\mathrm{RDD}_{2.5}$ size fraction is less apparent for the major elements (Fig. 4b, top), but for the trace elements (Fig. 4b, bottom) there are further enrichments in the metallic and metalloid elements, especially $\mathrm{Ni}, \mathrm{Sn}$ and $\mathrm{Cu}$. Common patterns were found concerning the elements enriched in the RDD fractions compared to the $\mathrm{DD}_{500}$. This is mainly the case for $\mathrm{Zn}, \mathrm{Sb}, \mathrm{As}, \mathrm{Sn}$ and $\mathrm{Pb}$ which were probably mostly sourced from the wear of 

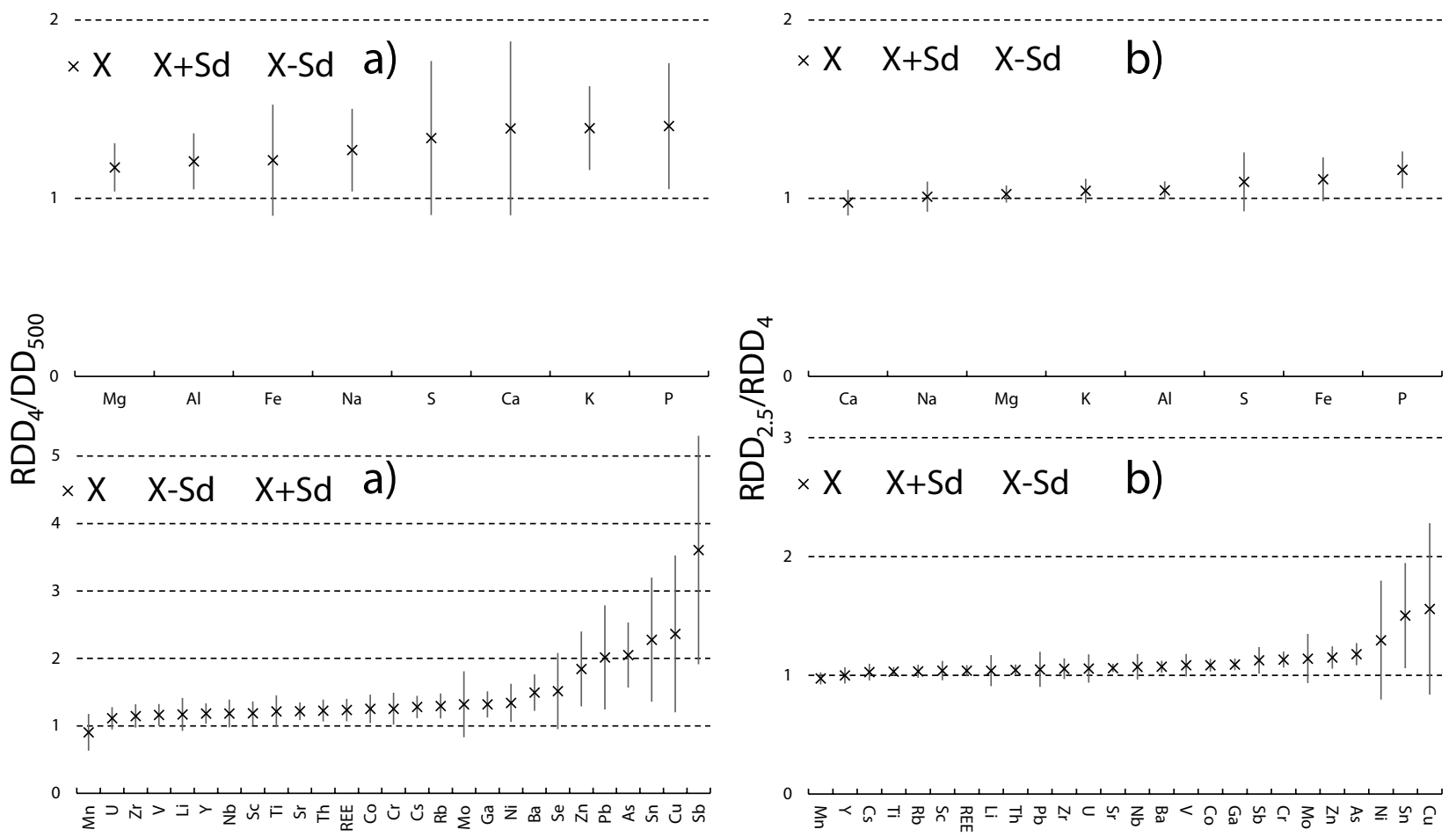

Fig. 4 a Average $\mathrm{RDD}_{4} / \mathrm{DD}_{500}$ major and trace element ratios and standard deviation for the Velenje Coal Basin samples. b Average $\mathrm{RDD}_{2.5} /$ $\mathrm{RDD}_{4}$ major and trace element ratios and standard deviation for the Velenje Coal Basin samples

mining machinery and from sulphide minerals in the coal. In contrast, $\mathrm{Mn}$ is the only trace element which decreases in its concentration in the finest fractions $\left(\mathrm{RDD}_{4}\right.$ and $\left.\mathrm{RDD}_{2.5}\right)$ when compared to $\mathrm{DD}_{500}$ (Fig. $4 \mathrm{a}$ and $4 \mathrm{~b}$, bottom). This result is similar to previous results from Trechera et al. $(2020,2021)$. Mn is probably joined with organic matter (producing coarser particles), which is commonly associated with carbonate minerals (Swaine 1990).

\subsubsection{Upper silesian coal basin samples}

Representative coal samples from five of the USCB mines (Pniowek, Jankowice, Marcel, Bielszowice and MurckiStaszic) were analysed (Tables S10, S11 and S12). Elemental concentrations were generally $<1.5 \times$ the average worldwide coal concentrations reported by Ketris and Yudovich (2009) (Table S9), although only Bielszowice mine samples meet the $<1.5$ factor for all elements. Other exceptions are for $\mathrm{Mn}(1.5 \times$ in the Marcel mine), $\mathrm{Zn}, \mathrm{Pb}$ and $\mathrm{Co}(1.6 \mathrm{x}$, $1.8 \mathrm{x}$, and $2.8 \times$ respectively in Jankowice mine), $\mathrm{Y}(1.8 \mathrm{x})$, $\mathrm{Zn}(2.1 \mathrm{x}), \mathrm{Sr}(2.6 \mathrm{x}), \mathrm{Ba}(2.8 \mathrm{x}), \mathrm{Sn}(3.2 \mathrm{x})$ and $\mathrm{P}(6.7 \mathrm{x})$ in the Pniowek mine, and $\mathrm{Ba}(1.5 \mathrm{x}), \mathrm{Co}(1.5-1.7 \mathrm{x}), \mathrm{W}(1.6 \mathrm{x}), \mathrm{Cu}$ (2.0x), Sb (2.2x), Pb (1.8-4.9x), Zn (6.4x) and Mn (5.0-12x) in Murcki-Staszic.

\subsubsection{Deposited dust samples $\left(\mathrm{DD}_{500}\right)$}

When $\mathrm{DD}_{500}$ samples (Table S16 and S17) are compared with their parent coals, most major elements in all USCB $\mathrm{DD}_{500}$ samples had increased concentrations, by at least two times, when compared with parent coals, with the exception of S, and P (in Pniowek), which reached 0.4-1.4 times, and 0.9 times, respectively.

In the case of $\mathrm{S}$, its content in coal dusts was lower than (or similar) to the parent coal in all USCB mines. This is likely related to $S$ mostly occurring in the coal matrix and therefore coming from the organic part of the $\mathrm{DD}_{500}$, and accordingly these (enriched in mineral matter) contain lower $\mathrm{S}$ than the parent coals. The content in pyrite in these coal dusts is presumably minimal due to their low S loads (Kotarba 2001). Ca shows a strongly increased concentration in the $\mathrm{DD}_{500}$ samples when compared to the parent coals (20-300 times). This effect is attributed to the walls of these USCB mines being shotcrete with concrete to prevent collapses, although additional input of calcium carbonate from the coal gangue cannot be excluded. In addition to this, carbonate 'rock dust' is spread in some parts of the underground mines to prevent explosions. Also K concentrations are markedly higher (4 times) in the $\mathrm{DD}_{500}$ compared with their parent coals in all USCB underground mines, with the exception of the Jankowice mine. This observation is attributed to the higher mineral matter loads in the dust. 


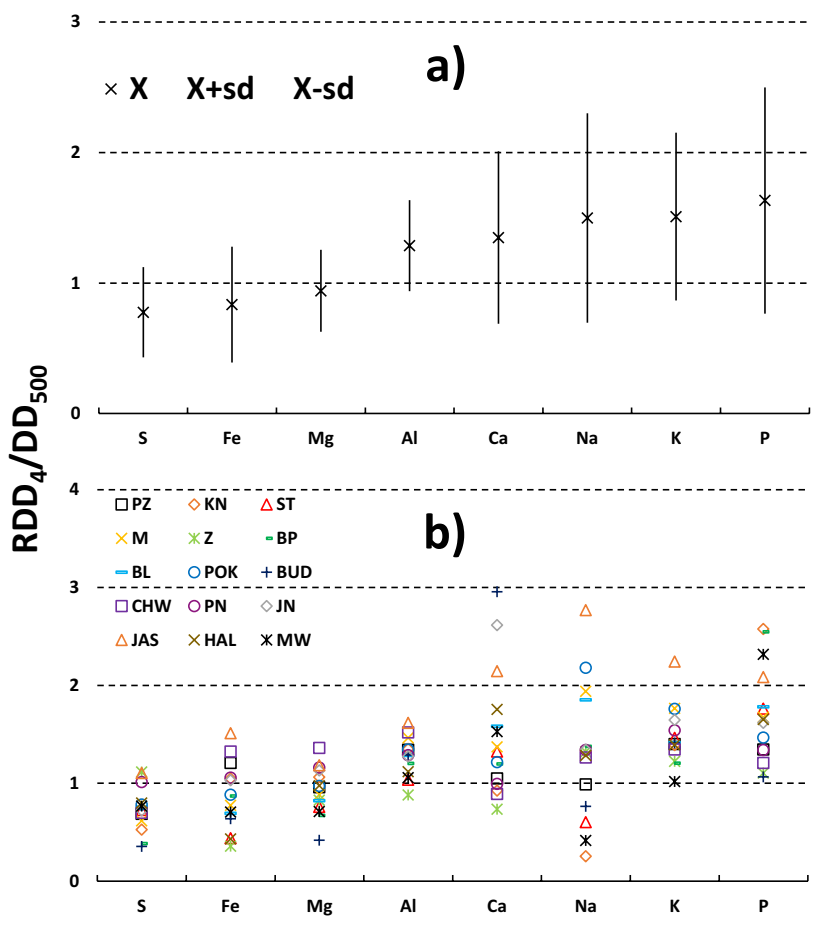

Fig. 5 a Averaged major element $\mathrm{RDD}_{4} / \mathrm{DD}_{500}$ ratios for all samples from the Upper Silesian Coal Basin. b Averaged major element $\mathrm{RDD}_{4} / \mathrm{DD}_{500}$ ratios for samples from individual mines in the Upper Silesian Coal Basin. c Averaged trace element $\mathrm{RDD}_{4} / \mathrm{DD}_{500}$ ratios for all samples from Upper Silesian Coal Basin. d Averaged trace element $\mathrm{RDD}_{4} / \mathrm{DD}_{500}$ ratios for samples from individual mines in the

With regard to trace element concentrations, most trace element concentrations were higher or very similar in $\mathrm{DD}_{500}$ than in the parent coal, with the exceptions of As, $\mathrm{Co}, \mathrm{Pb}$, $\mathrm{Mn}$ and $\mathrm{Ge}$ in the Murcki-Staszic mine; $\mathrm{Co}$ and $\mathrm{Ni}$ in the Marcel mine and As, Co, Mo and Ni in the Jankowice mine.

\subsubsection{Respirable deposited dust samples $\left(\mathrm{RDD}_{4}\right)$}

Average concentrations of major elements in $\mathrm{RDD}_{4}$ and $\mathrm{DD}_{500}$ samples again show a marked enrichment in $\mathrm{Al}, \mathrm{Ca}$, $\mathrm{Na}, \mathrm{K}, \mathrm{P}$ in the $\mathrm{RDD}_{4}$ fraction (Tables S16 to S19), with the exception of $\mathrm{S}, \mathrm{Fe}$ and $\mathrm{Mg}$ which are enriched in the $\mathrm{DD}_{500}$, and accordingly in the coarser fractions (Fig. 5a). Thus, in $13(\mathrm{~S}), 11(\mathrm{Fe})$ and $10(\mathrm{Mg})$ out of 15 USCB mines, $\mathrm{RDD}_{4} /$ $\mathrm{DD}_{500}$ ratios are $<1$ (Fig. 5b). In contrast, $\mathrm{Al}$ ratio generally slightly exceeds 1 , and this ratio is even $>2$ in some cases for $\mathrm{Ca}, \mathrm{Na}, \mathrm{K}$ and $\mathrm{P}$.

$\mathrm{RDD}_{4} / \mathrm{DD}_{500}$ ratios for trace element concentrations are shown in Fig. 5c and d, with considerable variations, but a clear trend towards the enrichment of metals in the $\mathrm{RDD}_{4}$. Elements such as $\mathrm{Cu}, \mathrm{Sn}, \mathrm{Zn}$ and As are concentrated by 1.5-1.7 times, but it is the metalloid $\mathrm{Sb}$ that is most enriched (2.5 times). However, Fig. 5c also highlights major geochemical variations (high standard deviations) for average

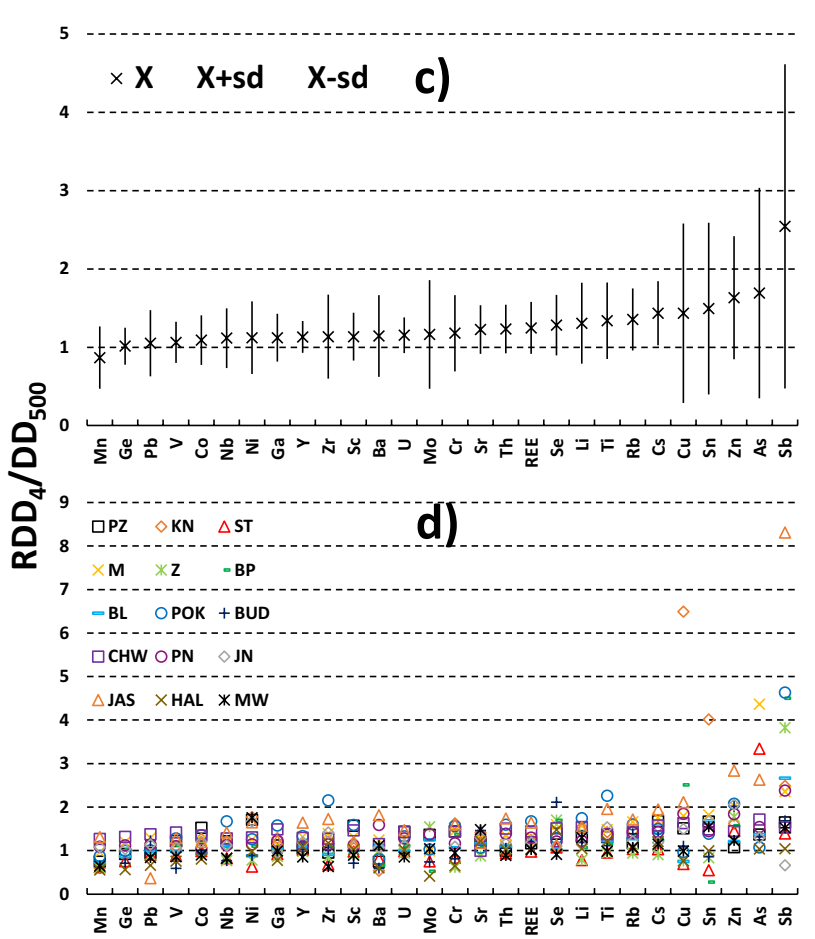

Upper Silesian Coal Basin. PZ, Piast-Ziemowit; KN, Knurów; ST, Murcki-Staszic; M, Marcel; Z, Zofiowka; BP, Bobrek-Piekary; BL, Bielszowice; POK, Pokój; BUD, Budryk; CHW, Chwalowice; PN, Pniowek; JN, Jankowice; JAS, Jastrzebie; HAL, Halemba; MW, Myslowice-Wesola

dusts. The least fractionated metallic element is $\mathrm{Mn}$, with enrichments in only five mines (Marcel, Chwalowice, Pniowek, Jankowice, and Jastrzebie). In contrast, $\mathrm{Zr}$, Se and Ti reach $\mathrm{RDD}_{4} / \mathrm{DD}_{500}$ ratios $>2$ in some cases; and $\mathrm{Cu}, \mathrm{Sn}, \mathrm{Zn}$, $\mathrm{As}$ and $\mathrm{Sb}$ often reach $>3$.

In summary, the results show that neither the parent coal, nor the $\mathrm{DD}_{500}$ have geochemical patterns reproducing those of the respirable dust $\left(\mathrm{RDD}_{4}\right)$, specially for some metals.

\section{3 $\mathrm{PM}_{10}$ measurements}

\subsubsection{Velenje coal basin $\mathrm{PM}_{10}$ concentrations}

$\mathrm{PM}_{10}$ airborne concentrations in the VCB mine were measured during coal working using CIP10 samplers at different distances from long-wall shearer operations (50, 100, 150 and $200 \mathrm{~m}$ ). Here, the shearer moves along to cut a section of the coal seam then is progressed forwards by large hydraulic push rams, attached to roof supports, to cut the next section (Reid et al. 2006).

No reference on occupational exposure limits was found for ambient concentrations of metals in Slovenia. According to the occupational exposure limits for airborne toxic substances from Poland (Basic Legal Act in Poland 2010), 
Table $1 \mathrm{PM}_{10}$ levels and major element oxide and trace element concentrations in $\mathrm{PM}_{10}$ per $\mathrm{m}^{3}$ of air in the Velenje Coal Basin mine during shearer-longwall operations at a T-junction (exhaust air from longwall face), longwall k-95

\begin{tabular}{|c|c|c|c|c|c|}
\hline Activity distance (m) & 0 & 50 & 100 & 150 & 200 \\
\hline $\mathrm{PM}_{10}\left(\mu \mathrm{g} / \mathrm{m}^{3}\right)$ & 5410 & 5135 & 4814 & 4994 & 3500 \\
\hline Sampling minutes & 105 & 100 & 95 & 83 & 155 \\
\hline $\operatorname{Coal}\left(\mu \mathrm{g} / \mathrm{m}^{3}\right)$ & 1400 & 1317 & 1280 & 1242 & 878 \\
\hline $\mathrm{SiO}_{2}\left(\mu \mathrm{g} / \mathrm{m}^{3}\right)$ & 167 & 167 & 174 & 169 & 119 \\
\hline $\mathrm{Al}_{2} \mathrm{O}_{3}\left(\mu \mathrm{g} / \mathrm{m}^{3}\right)$ & 112 & 111 & 116 & 113 & 79 \\
\hline $\mathrm{CaO}\left(\mu \mathrm{g} / \mathrm{m}^{3}\right)$ & 100 & 88 & 97 & 97 & 62 \\
\hline $\mathrm{Fe}_{2} \mathrm{O}_{3}\left(\mu \mathrm{g} / \mathrm{m}^{3}\right)$ & 132 & 125 & 134 & 123 & 95 \\
\hline $\mathrm{K}_{2} \mathrm{O}\left(\mu \mathrm{g} / \mathrm{m}^{3}\right)$ & 94 & 67 & 13 & 13 & 8.4 \\
\hline $\operatorname{MgO}\left(\mu \mathrm{g} / \mathrm{m}^{3}\right)$ & 18 & 16 & 18 & 17 & 11 \\
\hline $\mathrm{Na}_{2} \mathrm{O}\left(\mu \mathrm{g} / \mathrm{m}^{3}\right)$ & 31 & 37 & 31 & 38 & 25 \\
\hline $\mathrm{S}\left(\mu \mathrm{g} / \mathrm{m}^{3}\right)$ & 120 & 117 & 124 & 115 & 85 \\
\hline $\mathrm{TiO}_{2}\left(\mu \mathrm{g} / \mathrm{m}^{3}\right)$ & 4.7 & 4.4 & 5.1 & 4.3 & 3.1 \\
\hline $\mathrm{Li}\left(\mathrm{ng} / \mathrm{m}^{3}\right)$ & 35 & 49 & 29 & 36 & 26 \\
\hline $\mathrm{Sc}\left(\mathrm{ng} / \mathrm{m}^{3}\right)$ & $<2$ & $<2$ & $<2$ & $<2$ & $<2$ \\
\hline $\mathrm{V}\left(\mathrm{ng} / \mathrm{m}^{3}\right)$ & 85 & 79 & 84 & 80 & 59 \\
\hline $\mathrm{Cr}\left(\mathrm{ng} / \mathrm{m}^{3}\right)$ & 132 & 125 & 145 & 222 & 95 \\
\hline $\operatorname{Mn}\left(\mathrm{ng} / \mathrm{m}^{3}\right)$ & 839 & 780 & 800 & 745 & 553 \\
\hline $\mathrm{Co}\left(\mathrm{ng} / \mathrm{m}^{3}\right)$ & 11 & 9.9 & 10 & 9.9 & 8.0 \\
\hline $\mathrm{Ni}\left(\mathrm{ng} / \mathrm{m}^{3}\right)$ & 20 & 14 & 18 & 127 & 18 \\
\hline $\mathrm{Cu}\left(\mathrm{ng} / \mathrm{m}^{3}\right)$ & 124 & 156 & 171 & 245 & 140 \\
\hline $\mathrm{Zn}\left(\mathrm{ng} / \mathrm{m}^{3}\right)$ & 1026 & 1871 & 1009 & 1042 & 902 \\
\hline $\mathrm{Ga}\left(\mathrm{ng} / \mathrm{m}^{3}\right)$ & 18 & 17 & 18 & 18 & 13 \\
\hline As $\left(n g / m^{3}\right)$ & 35 & 41 & 38 & 41 & 29 \\
\hline $\mathrm{Rb}\left(\mathrm{ng} / \mathrm{m}^{3}\right)$ & 91 & 88 & 88 & 83 & 65 \\
\hline $\mathrm{Sr}\left(\mathrm{ng} / \mathrm{m}^{3}\right)$ & 443 & 379 & 377 & 441 & 280 \\
\hline $\mathrm{Y}\left(\mathrm{ng} / \mathrm{m}^{3}\right)$ & 15 & 14 & 15 & 14 & 9.8 \\
\hline $\mathrm{Zr}\left(\mathrm{ng} / \mathrm{m}^{3}\right)$ & 76 & 50 & 51 & 46 & 42 \\
\hline $\mathrm{Nb}\left(\mathrm{ng} / \mathrm{m}^{3}\right)$ & 10 & $<2$ & $<2$ & $<2$ & 6.5 \\
\hline $\operatorname{Mo}\left(\mathrm{ng} / \mathrm{m}^{3}\right)$ & 74 & 70 & 73 & 66 & 56 \\
\hline $\mathrm{Sb}\left(\mathrm{ng} / \mathrm{m}^{3}\right)$ & 636 & 655 & 642 & 578 & 621 \\
\hline $\mathrm{Cs}\left(\mathrm{ng} / \mathrm{m}^{3}\right)$ & $<2$ & $<2$ & $<2$ & $<2$ & 6.8 \\
\hline $\mathrm{Ba}\left(\mathrm{ng} / \mathrm{m}^{3}\right)$ & 296 & 286 & 330 & 293 & 221 \\
\hline $\mathrm{Pb}\left(\mathrm{ng} / \mathrm{m}^{3}\right)$ & 83 & 72 & 53 & 76 & 52 \\
\hline $\operatorname{Th}\left(\mathrm{ng} / \mathrm{m}^{3}\right)$ & $<2$ & $<2$ & $<2$ & $<2$ & $<2$ \\
\hline $\mathrm{U}\left(\mathrm{ng} / \mathrm{m}^{3}\right)$ & 28 & 26 & 29 & 25 & 19 \\
\hline $\operatorname{REE}\left(\mathrm{ng} / \mathrm{m}^{3}\right)$ & 90 & 89 & 94 & 91 & 68 \\
\hline
\end{tabular}

measured elemental concentrations did not exceed the respective limit values.

As was expected, ambient $\mathrm{PM}_{10}$ concentrations progressively decreased with increasing distance from the long-wall shearer operations (Table 1). The general tendency was for constant element concentrations in $\mathrm{PM}_{10}$ in the VCB mine at a distance of $150 \mathrm{~m}$ from the shearer. At a distance of $200 \mathrm{~m}$ there was a slight decrease in their concentrations which is likely to have been due to the effectiveness of the long-wall "U-type" ventilation system, with a flow of new air coming into the workings (McPherson 1993; Smith et al. 1994; Marts et al. 2015), as well as the shearer spraying system reducing airborne dust concentrations (Colinet et al. 2010). There were a few exceptions to this such as for $\mathrm{Li}$ and $\mathrm{Zn}$ (50 $\mathrm{m}$ away) and $\mathrm{Cr}, \mathrm{Ni}$ and $\mathrm{Cu}$ (150 $\mathrm{m}$ away) where there were large increases in concentrations, with no clear explanation.

Another interesting pattern is the higher ambient concentrations of $\mathrm{Mn}$ and $\mathrm{Fe}_{2} \mathrm{O}_{3}$ in comparison with similar studies carried out in Chinese underground coal mines (Trechera et al. 2020, 2021), which are possibly from machine wear or from higher $\mathrm{Mn}$ and $\mathrm{Fe}$ contents in the Slovenian coals.

\subsubsection{Upper silesian coal basin $\mathrm{PM}_{10}$ concentrations}

Ambient $\mathrm{PM}_{10}$ concentrations in the different USCB underground coal mines were measured during two different coal mining activities: i) Shearer cutting during long-wall excavations (as for the VCB mine), ii) Roadway drivage, which consists of cutting the coal and rock using a road-header, loading and transportation of the excavated material and the installing of underground supports.

Tables 2, 3, 4 show $\mathrm{PM}_{10}$ concentrations in the Knurów, Murcki-Staszic, Pnioweck, Marcel, and Bielszowice underground coal mines. Ambient concentrations of all determined elements are lower than the Polish recommended maximum values for occupational environments (Basic Legal Act in Poland 2010). However, ambient $\mathrm{PM}_{10}$ concentrations should not exceed $4.0 \mathrm{mg} / \mathrm{m}^{3}$ where the coal contains $2 \%-10 \%$ of $\mathrm{SiO}_{2}$, or $2.0 \mathrm{mg} / \mathrm{m}^{3}$ with $10 \%-50 \%$ of $\mathrm{SiO}_{2}$ over a period of $8 \mathrm{~h}$. $\mathrm{PM}_{10}$ concentrations measured in various of the studied mines were above these values, such as in the Pniowek mine (9.8 to $12.0 \mathrm{mg} / \mathrm{m}^{3}$ coal dust concentration in zone $\mathrm{b}, 4.7$ to $6.0 \mathrm{mg} / \mathrm{m}^{3}$ in zone a and 14 to $24 \mathrm{mg} / \mathrm{m}^{3}$ in zone c, Table 3), Marcel mine ( 8.3 to $9.6 \mathrm{mg} /$ $\mathrm{m}^{3}$ in zone a, and 12 to $13 \mathrm{mg} / \mathrm{m}^{3}$ in zone b), Knurów mine ( 7.7 to $14.0 \mathrm{mg} / \mathrm{m}^{3}$, Table 2), and Bielszowice mine (3.3 to $6.1 \mathrm{mg} / \mathrm{m}^{3}$, Tables 3 and 4 ). However, these concentrations were measured over periods shorter than $8 \mathrm{~h}$, and therefore are not comparable with the occupational standard. In any case, these short time high concentrations reinforced the importance of the protocols applied by mining companies to protect coal workers with sophisticated personal protective equipment and coal dust abatement controls.

As expected, $\mathrm{PM}_{10}$ concentrations are mostly higher closer to mine machine operations (Tables 2, 3,4), with the exception of the Pniowek mine zone a, where measurements took place during a maintenance shift when mine machinery was switched off but the ventilation system continued to operate.

Comparing the two activities studied in all mines, shearer cutting during long-wall excavations emitted less $\mathrm{PM}_{10}$ coal dust than the roadway drivage operations. Mn concentrations 
Table $2 \mathrm{PM}_{10}$ levels and major element oxide and trace element concentrations during roadway drivage technique in Knurów mine (exhaust air from roadway face; 5b, seam 404/1) and shearer cutting- longwall advance in Murcki-Staszic mine at the T-junction (exhaust air from longwall face 03/seam 510) from the Upper Silesian Coal Basin

\begin{tabular}{|c|c|c|c|c|c|c|c|c|}
\hline Mine & Knurów & Knurów & Knurów & Murcki-Staszic & Murcki-Staszic & Murcki-Staszic & Murcki-Staszic & Murcki-Staszic \\
\hline Activity distance (m) & $20-50$ & $100-140$ & $220-280$ & 0 & 50 & 190 & 280 & 350 \\
\hline $\mathrm{PM}_{10}\left(\mu \mathrm{g} / \mathrm{m}^{3}\right)$ & 14,025 & 15,000 & 7702 & 11,905 & 7833 & 14,969 & 6578 & 7963 \\
\hline Sampling minutes & 80 & 80 & 95 & 95 & 87 & 97 & 94 & 99 \\
\hline $\operatorname{Coal}\left(\mu \mathrm{g} / \mathrm{m}^{3}\right)$ & 6221 & 6086 & 3299 & 613 & 538 & 843 & 672 & 486 \\
\hline $\mathrm{SiO}_{2}\left(\mu \mathrm{g} / \mathrm{m}^{3}\right)$ & 2669 & 2404 & 927 & 151 & 117 & 228 & 125 & 106 \\
\hline $\mathrm{Al}_{2} \mathrm{O}_{3}\left(\mu \mathrm{g} / \mathrm{m}^{3}\right)$ & 1780 & 1603 & 618 & 101 & 78 & 152 & 83 & 71 \\
\hline $\mathrm{CaO}\left(\mu \mathrm{g} / \mathrm{m}^{3}\right)$ & 296 & 751 & 1128 & 272 & 217 & 331 & 388 & 214 \\
\hline $\mathrm{Fe}_{2} \mathrm{O}_{3}\left(\mu \mathrm{g} / \mathrm{m}^{3}\right)$ & 712 & 651 & 272 & 74 & 79 & 106 & 50 & 66 \\
\hline $\mathrm{K}_{2} \mathrm{O}\left(\mu \mathrm{g} / \mathrm{m}^{3}\right)$ & 273 & 250 & 93 & 5.6 & 8.1 & 13 & 10 & 13 \\
\hline $\operatorname{MgO}\left(\mu \mathrm{g} / \mathrm{m}^{3}\right)$ & 180 & 151 & 69 & 32 & 32 & 44 & 27 & 22 \\
\hline $\mathrm{Na}_{2} \mathrm{O}\left(\mu \mathrm{g} / \mathrm{m}^{3}\right)$ & 146 & 121 & 96 & 57 & 55 & 86 & 61 & 52 \\
\hline $\mathrm{S}\left(\mu \mathrm{g} / \mathrm{m}^{3}\right)$ & 49 & 48 & 53 & 47 & 61 & 54 & 54 & 41 \\
\hline $\mathrm{TiO}_{2}\left(\mu \mathrm{g} / \mathrm{m}^{3}\right)$ & 89 & 82 & 32 & 7.1 & 5.5 & 9.7 & 8.1 & 5.1 \\
\hline $\mathrm{Li}\left(\mathrm{ng} / \mathrm{m}^{3}\right)$ & 575 & 566 & 206 & 99 & 74 & 91 & 50 & 79 \\
\hline $\mathrm{Sc}\left(\mathrm{ng} / \mathrm{m}^{3}\right)$ & 168 & 150 & 50 & $<2$ & $<2$ & $<2$ & $<2$ & $<2$ \\
\hline $\mathrm{V}\left(\mathrm{ng} / \mathrm{m}^{3}\right)$ & 1048 & 979 & 345 & 58 & 40 & 83 & 46 & 37 \\
\hline $\mathrm{Cr}\left(\mathrm{ng} / \mathrm{m}^{3}\right)$ & 1243 & 1130 & 426 & 75 & 89 & 654 & 80 & 78 \\
\hline $\operatorname{Mn}\left(\mathrm{ng} / \mathrm{m}^{3}\right)$ & 10,646 & 9736 & 3593 & 511 & 467 & 748 & 421 & 455 \\
\hline $\mathrm{Co}\left(\mathrm{ng} / \mathrm{m}^{3}\right)$ & 176 & 156 & 55 & $<2$ & $<2$ & 17 & 9.7 & 6.9 \\
\hline $\mathrm{Ni}\left(\mathrm{ng} / \mathrm{m}^{3}\right)$ & 446 & 375 & 152 & $<2$ & 6.87 & 553 & $<2$ & $<2$ \\
\hline $\mathrm{Cu}\left(\mathrm{ng} / \mathrm{m}^{3}\right)$ & 398 & 547 & 374 & $<2$ & 848 & 93 & 81 & 31 \\
\hline $\mathrm{Zn}\left(\mathrm{ng} / \mathrm{m}^{3}\right)$ & 1569 & 1419 & 1020 & 488 & 1611 & 2179 & 4686 & 1366 \\
\hline $\mathrm{Ga}\left(\mathrm{ng} / \mathrm{m}^{3}\right)$ & 242 & 225 & 75 & $<2$ & 12 & 21 & 13 & 10 \\
\hline As $\left(n g / m^{3}\right)$ & 51 & 46 & 25 & $<2$ & 2.2 & 143 & $<2$ & $<2$ \\
\hline $\mathrm{Rb}\left(\mathrm{ng} / \mathrm{m}^{3}\right)$ & 1206 & 1086 & 384 & 36 & 33 & 62 & 37 & 29 \\
\hline $\mathrm{Sr}\left(\mathrm{ng} / \mathrm{m}^{3}\right)$ & 1248 & 1532 & 1277 & 509 & 1021 & 764 & 589 & 426 \\
\hline$Y\left(n g / m^{3}\right)$ & 243 & 228 & 83 & $<2$ & $<2$ & $<2$ & 11 & 10 \\
\hline $\mathrm{Zr}\left(\mathrm{ng} / \mathrm{m}^{3}\right)$ & 1111 & 871 & 296 & 38 & 44 & 64 & 43 & 32 \\
\hline $\mathrm{Nb}\left(\mathrm{ng} / \mathrm{m}^{3}\right)$ & 137 & 122 & 44 & $<2$ & $<2$ & $<2$ & $<2$ & $<2$ \\
\hline $\operatorname{Mo}\left(\mathrm{ng} / \mathrm{m}^{3}\right)$ & $<2$ & $<2$ & $<2$ & $<2$ & $<2$ & $<2$ & 12 & $<2$ \\
\hline $\mathrm{Sb}\left(\mathrm{ng} / \mathrm{m}^{3}\right)$ & 133 & 245 & 246 & 626 & 965 & 897 & 393 & 738 \\
\hline $\mathrm{Cs}\left(\mathrm{ng} / \mathrm{m}^{3}\right)$ & 73 & 65 & 25 & $<2$ & $<2$ & $<2$ & $<2$ & $<2$ \\
\hline $\mathrm{Ba}\left(\mathrm{ng} / \mathrm{m}^{3}\right)$ & 4368 & 3949 & 1555 & 806 & 829 & 1358 & 9778 & 1089 \\
\hline $\mathrm{Pb}\left(\mathrm{ng} / \mathrm{m}^{3}\right)$ & 277 & 247 & 142 & 10 & 70 & 157 & 113 & 46 \\
\hline $\mathrm{Th}\left(\mathrm{ng} / \mathrm{m}^{3}\right)$ & 124 & 121 & 42 & $<2$ & $<2$ & $<2$ & $<2$ & $<2$ \\
\hline $\mathrm{U}\left(\mathrm{ng} / \mathrm{m}^{3}\right)$ & 41 & 38 & 16 & $<2$ & $<2$ & $<2$ & $<2$ & $<2$ \\
\hline $\operatorname{REE}\left(\mathrm{ng} / \mathrm{m}^{3}\right)$ & 1724 & 1562 & 588 & 68 & 67 & 130 & 71 & 66 \\
\hline
\end{tabular}

were also clearly higher during roadway drivage. When comparing the different coal mines, lower $\mathrm{PM}_{10}$ concentrations were recorded in three mines, Murcki-Staszic, Pniowek zone $\mathrm{b}$ and Bielszowice. In contrast, in the Knurów mine, concentrations of $\mathrm{Al}_{2} \mathrm{O}_{3}, \mathrm{CaO}, \mathrm{Fe}_{2} \mathrm{O}_{3}, \mathrm{~K}_{2} \mathrm{O}, \mathrm{MgO}, \mathrm{Na}_{2} \mathrm{O}$, as well as metals such as $\mathrm{Pb}$ and $\mathrm{Cr}$, were higher in comparison with other mines from this and other studies (Trechera et al. 2020, 2021).

When $\mathrm{PM}_{10}$ levels produced by each mining activity are compared, elevated levels of As (2.2 times), Ba (1.5 times), and Li (2.2 times) are evidenced in the Pniowek zone c, and $\mathrm{Zn}$ (1.7-2.3 times, $\mathrm{Ba}$ (1.5 times) and $\mathrm{Cu}$ (2 times) in the Marcel mine (zones a and b). The elevated levels of these metals were likely derived from a mix of sources including machine wear $(\mathrm{Cu}, \mathrm{Zn}, \mathrm{Ba})$, resuspension of DD from the floor and walls (As, Ba, Li), and PM brought from other zones of the mine by the ventilation system. 
Table $3 \mathrm{PM}_{10}$ levels and major element oxide and trace element concentrations in the Pnioweck mine from the Upper Silesian Coal Basin. Zone a) Roadway drivage technique (exhaust air from roadway face PW-1, seam 358/16). Zone b) Shearer cutting-longwall advance at the T-junction (exhaust air from longwall face B-4, seam 404/2). Zone c) Roadway drivage technique (exhaust air from roadway face seam K-9, seam 363 362/3)

\begin{tabular}{|c|c|c|c|c|c|c|c|c|c|c|c|c|}
\hline Zone & $\mathrm{a}$ & $\mathrm{a}$ & $\mathrm{a}$ & $\mathrm{b}$ & $\mathrm{b}$ & $\mathrm{b}$ & $\mathrm{b}$ & $\mathrm{c}$ & $\mathrm{c}$ & $\mathrm{c}$ & $\mathrm{c}$ & $\mathrm{c}$ \\
\hline Activity distance (m) & 60 & 120 & 180 & 0 & 50 & 100 & 150 & 0 & 50 & 100 & 150 & 200 \\
\hline $\mathrm{PM}_{10}\left(\mu \mathrm{g} / \mathrm{m}^{3}\right)$ & 4669 & 4602 & 5975 & 10,544 & 11,464 & 10,325 & 9843 & 24,343 & 10,474 & 17,480 & 17,710 & 13,405 \\
\hline Sampling minutes & 96 & 93 & 85 & 125 & 125 & 120 & 115 & 105 & 103 & 70 & 60 & 83 \\
\hline Coal $\left(\mu \mathrm{g} / \mathrm{m}^{3}\right)$ & 1794 & 1721 & 2193 & 2346 & 2136 & 2975 & 3145 & 9245 & 5919 & 7052 & 7589 & 6329 \\
\hline $\mathrm{SiO}_{2}\left(\mu \mathrm{g} / \mathrm{m}^{3}\right)$ & 809 & 783 & 1013 & 566 & 534 & 834 & 861 & 1969 & 1247 & 1493 & 1603 & 1317 \\
\hline $\mathrm{Al}_{2} \mathrm{O}_{3}\left(\mu \mathrm{g} / \mathrm{m}^{3}\right)$ & 539 & 522 & 675 & 377 & 356 & 556 & 574 & 1312 & 831 & 995 & 1068 & 878 \\
\hline $\mathrm{CaO}\left(\mu \mathrm{g} / \mathrm{m}^{3}\right)$ & 194 & 154 & 168 & 230 & 197 & 156 & 187 & 243 & 164 & 182 & 179 & 177 \\
\hline $\mathrm{Fe}_{2} \mathrm{O}_{3}\left(\mu \mathrm{g} / \mathrm{m}^{3}\right)$ & 184 & 186 & 250 & 68 & 70 & 111 & 106 & 353 & 212 & 266 & 294 & 239 \\
\hline $\mathrm{K}_{2} \mathrm{O}\left(\mu \mathrm{g} / \mathrm{m}^{3}\right)$ & 79 & 75 & 99 & 84 & 44 & 68 & 72 & 179 & 109 & 138 & 148 & 119 \\
\hline $\mathrm{MgO}\left(\mu \mathrm{g} / \mathrm{m}^{3}\right)$ & 41 & 35 & 56 & 18 & 17 & 19 & 27 & 81 & 49 & 51 & 62 & 57 \\
\hline $\mathrm{Na}_{2} \mathrm{O}\left(\mu \mathrm{g} / \mathrm{m}^{3}\right)$ & 50 & 56 & 62 & 38 & 40 & 30 & 48 & 71 & 66 & 74 & 89 & 77 \\
\hline $\mathrm{S}\left(\mu \mathrm{g} / \mathrm{m}^{3}\right)$ & 44 & 49 & 46 & 49 & 44 & 41 & 41 & 98 & 80 & 88 & 98 & 86 \\
\hline $\mathrm{TiO}_{2}\left(\mu \mathrm{g} / \mathrm{m}^{3}\right)$ & 27 & 27 & 34 & 25 & 22 & 29 & 34 & 61 & 37 & 44 & 46 & 40 \\
\hline $\mathrm{Li}\left(\mathrm{ng} / \mathrm{m}^{3}\right)$ & 264 & 266 & 350 & 238 & 221 & 335 & 318 & 859 & 607 & 695 & 699 & 672 \\
\hline $\mathrm{Sc}\left(\mathrm{ng} / \mathrm{m}^{3}\right)$ & 48 & 47 & 61 & 38 & 37 & 53 & 52 & 136 & 79 & 102 & 104 & 82 \\
\hline $\mathrm{V}\left(\mathrm{ng} / \mathrm{m}^{3}\right)$ & 405 & 410 & 509 & 572 & 525 & 554 & 559 & 1307 & 827 & 974 & 995 & 822 \\
\hline $\mathrm{Cr}\left(\mathrm{ng} / \mathrm{m}^{3}\right)$ & 372 & 351 & 597 & 436 & 359 & 414 & 441 & 957 & 605 & 710 & 770 & 619 \\
\hline $\operatorname{Mn}\left(\mathrm{ng} / \mathrm{m}^{3}\right)$ & 2012 & 2098 & 3036 & 483 & 471 & 780 & 752 & 3654 & 1997 & 2555 & 2827 & 2262 \\
\hline $\operatorname{Co}\left(\mathrm{ng} / \mathrm{m}^{3}\right)$ & 57 & 55 & 74 & 92 & 89 & 75 & 80 & 169 & 107 & 126 & 136 & 111 \\
\hline $\mathrm{Ni}\left(\mathrm{ng} / \mathrm{m}^{3}\right)$ & 235 & 69 & 316 & 288 & 172 & 205 & 197 & 542 & 348 & 382 & 416 & 305 \\
\hline $\mathrm{Cu}\left(\mathrm{ng} / \mathrm{m}^{3}\right)$ & 125 & 10 & 1104 & 178 & 70 & 115 & 149 & 295 & 178 & 176 & 82 & 101 \\
\hline $\mathrm{Zn}\left(\mathrm{ng} / \mathrm{m}^{3}\right)$ & 1187 & 828 & 1389 & 1136 & 321 & 268 & 706 & 2156 & 1801 & 2744 & 1845 & 2217 \\
\hline $\mathrm{Ga}\left(\mathrm{ng} / \mathrm{m}^{3}\right)$ & 77 & 80 & 98 & 64 & 62 & 85 & 86 & 198 & 122 & 147 & 155 & 129 \\
\hline As $\left(n g / m^{3}\right)$ & 40 & 17 & 84 & 72 & 7.5 & 10 & 34 & 311 & 110 & 154 & 141 & 84 \\
\hline $\mathrm{Rb}\left(\mathrm{ng} / \mathrm{m}^{3}\right)$ & 403 & 391 & 514 & 275 & 253 & 415 & 405 & 1066 & 635 & 779 & 818 & 677 \\
\hline $\mathrm{Sr}\left(\mathrm{ng} / \mathrm{m}^{3}\right)$ & 660 & 597 & 726 & 718 & 694 & 683 & 754 & 1798 & 1223 & 1416 & 1509 & 1277 \\
\hline $\mathrm{Y}\left(\mathrm{ng} / \mathrm{m}^{3}\right)$ & 73 & 70 & 96 & 53 & 54 & 69 & 73 & 204 & 130 & 149 & 161 & 130 \\
\hline $\mathrm{Zr}\left(\mathrm{ng} / \mathrm{m}^{3}\right)$ & 373 & 343 & 493 & 188 & 189 & 265 & 489 & 816 & 479 & 547 & 591 & 480 \\
\hline $\mathrm{Nb}\left(\mathrm{ng} / \mathrm{m}^{3}\right)$ & 46 & 44 & 57 & 45 & 42 & 53 & 65 & 121 & 72 & 82 & 88 & 72 \\
\hline Mo $\left(\mathrm{ng} / \mathrm{m}^{3}\right)$ & $<2$ & $<2$ & $<2$ & $<2$ & $<2$ & $<2$ & $<2$ & 32 & 9 & $<2$ & $<2$ & $<2$ \\
\hline $\mathrm{Sb}\left(\mathrm{ng} / \mathrm{m}^{3}\right)$ & 296 & 265 & 305 & 340 & 358 & 258 & 318 & 888 & 634 & 606 & 584 & 682 \\
\hline Cs $\left(\mathrm{ng} / \mathrm{m}^{3}\right)$ & 41 & 42 & 51 & 34 & 31 & 48 & 45 & 104 & 67 & 79 & 86 & 69 \\
\hline $\mathrm{Ba}\left(\mathrm{ng} / \mathrm{m}^{3}\right)$ & 1816 & 1765 & 2354 & 1977 & 1961 & 2196 & 2243 & 5695 & 3489 & 4064 & 4239 & 3590 \\
\hline $\mathrm{Pb}\left(\mathrm{ng} / \mathrm{m}^{3}\right)$ & 116 & 148 & 291 & 240 & 109 & 99 & 145 & 232 & 140 & 141 & 184 & 125 \\
\hline $\operatorname{Th}\left(\mathrm{ng} / \mathrm{m}^{3}\right)$ & 43 & 42 & 46 & 25 & 27 & 36 & 56 & 101 & 64 & 71 & 80 & 65 \\
\hline $\mathrm{U}\left(\mathrm{ng} / \mathrm{m}^{3}\right)$ & 15 & $<2$ & 19 & $<2$ & $<2$ & $<2$ & $<2$ & 42 & 27 & 32 & 35 & 13 \\
\hline $\operatorname{REE}\left(\mathrm{ng} / \mathrm{m}^{3}\right)$ & 609 & 562 & 799 & 415 & 404 & 576 & 586 & 1537 & 941 & 1130 & 1131 & 959 \\
\hline
\end{tabular}

\section{4 $\mathrm{PM}_{10}$ and $\mathrm{RDD}_{4}$ comparison}

The aim of comparing $\mathrm{PM}_{10}$ and $\mathrm{RDD}_{4}$ concentrations was to find the possible sources of each particle size fraction to clarify the dominant type of particle present in underground coal mine air, always in a qualitative way. The comparison was performed by calculating the difference in $\mathrm{PM}_{10}$ concentrations (Tables 1, 2, 3,4) of major and trace elements.
In the VCB underground mine, all element concentrations in $\mathrm{PM}_{10}$ were lower than in the $\mathrm{RDD}_{4}$. Some elements, such as $\mathrm{K}, \mathrm{Cu}, \mathrm{Zn}$, and Mo, were similar in both $\mathrm{PM}_{10}$ and $\mathrm{RDD}_{4}$ samples, whereas $\mathrm{Na}$ and $\mathrm{Sb}$ show higher concentrations in $\mathrm{PM}_{10}$ from all sampling locations (1.3-2.0 times $\mathrm{Na}$ and 7.1-12 times higher $\mathrm{Sb}$ ).

In the case of the USCB mines, most elements in the Knurów mine show lower concentrations in the $\mathrm{PM}_{10}$ 
Table $4 \mathrm{PM}_{10}$ levels and major element oxide and trace element concentrations in different zones of Marcel (M) and Bielszowice (BL) mines from the Upper Silesian Coal Basin. M zone a: Shearer cutting-longwall advance at the T-junction (exhaust air from longwall face W-7, seam 505); M zone b): Roadway drivage technique (exhaust air from roadway face $\mathrm{C} 3$, seam 507); and $\mathrm{BL}$ : Roadway drivage technique (exhaust air from roadway face 4az, seam 510wd)

\begin{tabular}{|c|c|c|c|c|c|c|c|c|c|c|}
\hline Mine-zone & $\mathrm{M}-\mathrm{a}$ & M-a & M-a & M-b & M-b & M-b & M-b & $\mathrm{BL}$ & $\mathrm{BL}$ & BL \\
\hline Location & $20 \mathrm{~m}$ & $70 \mathrm{~m}$ & $120 \mathrm{~m}$ & $10 \mathrm{~m}$ & $40 \mathrm{~m}$ & $60 \mathrm{~m}$ & $80 \mathrm{~m}$ & $15 \mathrm{~m}$ & $40 \mathrm{~m}$ & $60 \mathrm{~m}$ \\
\hline Concentration $\left(\mu \mathrm{g} / \mathrm{m}^{3}\right)$ & 9590 & 8300 & 8255 & 12,181 & 12,960 & 12,505 & 12,242 & 6116 & 5627 & 3320 \\
\hline Sampling minutes & 160 & 150 & 140 & 105 & 100 & 95 & 95 & 155 & 150 & 140 \\
\hline $\operatorname{Coal}\left(\mu \mathrm{g} / \mathrm{m}^{3}\right)$ & 2018 & 1788 & 1814 & 4514 & 4812 & 4347 & 4678 & 1757 & 3492 & 1214 \\
\hline $\mathrm{SiO}_{2}\left(\mu \mathrm{g} / \mathrm{m}^{3}\right)$ & 450 & 396 & 398 & 1502 & 1625 & 1440 & 1548 & 425 & 853 & 811 \\
\hline $\mathrm{Al}_{2} \mathrm{O}_{3}\left(\mu \mathrm{g} / \mathrm{m}^{3}\right)$ & 300 & 264 & 265 & 1001 & 1083 & 960 & 1032 & 283 & 569 & 541 \\
\hline $\mathrm{CaO}\left(\mu \mathrm{g} / \mathrm{m}^{3}\right)$ & 153 & 128 & 124 & 221 & 230 & 226 & 264 & 132 & 213 & 192 \\
\hline $\mathrm{Fe}_{2} \mathrm{O}_{3}\left(\mu \mathrm{g} / \mathrm{m}^{3}\right)$ & 105 & 100 & 107 & 344 & 339 & 325 & 337 & 65 & 134 & 128 \\
\hline $\mathrm{K}_{2} \mathrm{O}\left(\mu \mathrm{g} / \mathrm{m}^{3}\right)$ & 29 & 30 & 28 & 111 & 114 & 103 & 110 & 28 & 52 & 50 \\
\hline $\mathrm{MgO}\left(\mu \mathrm{g} / \mathrm{m}^{3}\right)$ & 30 & 26 & 25 & 74 & 80 & 72 & 79 & 11 & 34 & 31 \\
\hline $\mathrm{Na}_{2} \mathrm{O}\left(\mu \mathrm{g} / \mathrm{m}^{3}\right)$ & 59 & 53 & 58 & 24 & 26 & 31 & 29 & 6.1 & 17 & 13 \\
\hline $\mathrm{S}\left(\mu \mathrm{g} / \mathrm{m}^{3}\right)$ & 64 & 56 & 64 & 20 & 20 & 20 & 21 & $<2$ & 20 & 21 \\
\hline $\mathrm{TiO}_{2}\left(\mu \mathrm{g} / \mathrm{m}^{3}\right)$ & 13 & 12 & 12 & 42 & 45 & 40 & 43 & 16 & 29 & 28 \\
\hline $\mathrm{Li}\left(\mathrm{ng} / \mathrm{m}^{3}\right)$ & 91 & 81 & 64 & 495 & 420 & 310 & 399 & 119 & 187 & 156 \\
\hline $\mathrm{Sc}\left(\mathrm{ng} / \mathrm{m}^{3}\right)$ & 24 & 19 & 20 & 87 & 87 & 80 & 86 & 22 & 45 & 39 \\
\hline $\mathrm{V}\left(\mathrm{ng} / \mathrm{m}^{3}\right)$ & 196 & 177 & 176 & 648 & 670 & 593 & 642 & 194 & 302 & 285 \\
\hline $\mathrm{Cr}\left(\mathrm{ng} / \mathrm{m}^{3}\right)$ & 229 & 225 & 214 & 625 & 684 & 595 & 622 & 97 & 306 & 277 \\
\hline $\operatorname{Mn}\left(n g / m^{3}\right)$ & 951 & 927 & 946 & 2548 & 2544 & 2373 & 2544 & 598 & 1154 & 1082 \\
\hline $\mathrm{Co}\left(\mathrm{ng} / \mathrm{m}^{3}\right)$ & 31 & 27 & 26 & 82 & 79 & 74 & 80 & 59 & 126 & 118 \\
\hline $\mathrm{Ni}\left(\mathrm{ng} / \mathrm{m}^{3}\right)$ & 132 & 130 & 222 & 263 & 259 & 245 & 247 & 11 & 150 & 114 \\
\hline $\mathrm{Cu}\left(\mathrm{ng} / \mathrm{m}^{3}\right)$ & 96 & 640 & 108 & 572 & 629 & 573 & 520 & $<2$ & 147 & 148 \\
\hline $\mathrm{Zn}\left(\mathrm{ng} / \mathrm{m}^{3}\right)$ & 4584 & 4817 & 4600 & 3482 & 3497 & 3211 & 3625 & 478 & 1248 & 1101 \\
\hline $\mathrm{Ga}\left(\mathrm{ng} / \mathrm{m}^{3}\right)$ & 43 & 39 & 41 & 128 & 144 & 120 & 130 & 40 & 76 & 70 \\
\hline As $\left(n g / m^{3}\right)$ & 33 & 100 & 52 & 34 & 48.7 & 39 & 38 & 25 & 161 & 62 \\
\hline $\mathrm{Rb}\left(\mathrm{ng} / \mathrm{m}^{3}\right)$ & 171 & 150 & 151 & 569 & 593 & 525 & 570 & 117 & 212 & 202 \\
\hline $\operatorname{Sr}\left(\mathrm{ng} / \mathrm{m}^{3}\right)$ & 675 & 550 & 534 & 896 & 941 & 896 & 911 & 346 & 602 & 548 \\
\hline $\mathrm{Y}\left(\mathrm{ng} / \mathrm{m}^{3}\right)$ & 46 & 41 & 43 & 113 & 125 & 110 & 119 & 33 & 53 & 49 \\
\hline $\mathrm{Zr}\left(\mathrm{ng} / \mathrm{m}^{3}\right)$ & 142 & 139 & 128 & 499 & 533 & 463 & 503 & 118 & 252 & 248 \\
\hline $\mathrm{Nb}\left(\mathrm{ng} / \mathrm{m}^{3}\right)$ & 22 & 21 & 20 & 65 & 71 & 62 & 67 & 22 & 42 & 39 \\
\hline Mo $\left(\mathrm{ng} / \mathrm{m}^{3}\right)$ & 17 & 21 & 17 & $<2$ & $<2$ & $<2$ & $<2$ & $<2$ & $<2$ & $<2$ \\
\hline $\mathrm{Sb}\left(\mathrm{ng} / \mathrm{m}^{3}\right)$ & 2292 & 2030 & 2361 & 1539 & 1311 & 1279 & 1467 & 204 & 616 & 611 \\
\hline Cs $\left(\mathrm{ng} / \mathrm{m}^{3}\right)$ & 24 & 21 & 21 & 71 & 75 & 65 & 71 & $<2$ & 15 & 14 \\
\hline $\mathrm{Ba}\left(\mathrm{ng} / \mathrm{m}^{3}\right)$ & 1477 & 1302 & 1301 & 4011 & 4037 & 4022 & 3458 & 917 & 1400 & 1320 \\
\hline $\mathrm{Pb}\left(\mathrm{ng} / \mathrm{m}^{3}\right)$ & 67 & 164 & 57 & 114 & 132 & 97 & 104 & 7.3 & 85 & 86 \\
\hline $\mathrm{Th}\left(\mathrm{ng} / \mathrm{m}^{3}\right)$ & 21 & 21 & 18 & 50 & 58 & 53 & 55 & 24 & 38 & 37 \\
\hline $\mathrm{U}\left(\mathrm{ng} / \mathrm{m}^{3}\right)$ & 16 & 14 & 14 & 32 & 33 & 30 & 32 & $<2$ & 17 & 15 \\
\hline $\operatorname{REE}\left(\mathrm{ng} / \mathrm{m}^{3}\right)$ & 310 & 269 & 270 & 897 & 962 & 861 & 912 & 371 & 625 & 592 \\
\hline
\end{tabular}

samples compared to $\mathrm{RDD}_{4}$, with the exception of $\mathrm{Ti}, \mathrm{V}$, $\mathrm{Mn}, \mathrm{Cr}, \mathrm{Co}, \mathrm{Mg}, \mathrm{Ca}$ and $\mathrm{REE}$ in some specific locations. The Murcki-Staszic mine also showed most elements to be enriched in the $\mathrm{RDD}_{4}$ samples, except for $\mathrm{Sb}, \mathrm{Na}$, and $\mathrm{S}$ with higher concentrations in the $\mathrm{PM}_{10}$ samples in all locations (1.7 to 4.0 times for $\mathrm{Sb}, 1.4$ to 2.8 times for $\mathrm{Na}$ and 1.7 to 4.0 times for $\mathrm{S}$ ). $\mathrm{PM}_{10} / \mathrm{RDD}_{4}$ ratios in the Pniowek mine zone were normally between 1.0 to 2.0, with the exception of $\mathrm{Ba}, \mathrm{Sr}, \mathrm{Ca}, \mathrm{Sb}$ and $\mathrm{Co}$ that had a ratio $<1.0$, and $\mathrm{S}, \mathrm{Mn}$ and $\mathrm{Na}$ with ratios $>2.0$ (1.7 to $2.4,2.3$ to $2.8,3.3$ to 3.9, respectively). In zone $b$, all $\mathrm{PM}_{10} / \mathrm{RDD}_{4}$ ratios were below or close to 1 and in zone c Ni, Cu, Zn, As, Sr Mo, Pb, U and Ca concentrations were lower in the $\mathrm{PM}_{10}$ than $\mathrm{RDD}_{4}$.

In the Marcel mine zone a, only $\mathrm{Zn}$ (3.9 to 4.7), $\mathrm{Sb}$ (6.9 to 8.2) and $\mathrm{Na}$ (4.4 to 5.0) were markedly higher in the $\mathrm{PM}_{10}$ than $\mathrm{RDD}_{4}$, whereas Li, V, Cr, Mn, Cu, As, Sr, Y, Mo and Pb were enriched in the $\mathrm{RDD}_{4}$ samples. In contrast, in Marcel mine zone b, a large number of elements such as $\mathrm{Li}, \mathrm{Sc}, \mathrm{Ti}$, $\mathrm{Ga} \mathrm{Rb}, \mathrm{Zr}, \mathrm{Nb}, \mathrm{Cs}, \mathrm{Ba}, \mathrm{Al}, \mathrm{K}$ and $\mathrm{Sb}$, show $\mathrm{PM}_{10} / \mathrm{RDD}_{4}$ ratios higher than 2.5, especially in the case of $\mathrm{Sb}$ which had ratios of 3.5 to 4.4. Finally, in Bielszowice, most elements showed higher concentrations in the $\mathrm{PM}_{10}$ samples 
compared to their respective $\mathrm{RDD}_{4}$ sample, with the exception of $\mathrm{Ca}, \mathrm{Mg}, \mathrm{Na}, \mathrm{Sr}$ and $\mathrm{Pb}$.

In summary, some elements such as $\mathrm{Sb}, \mathrm{Zn}, \mathrm{Mn}, \mathrm{Na}$, and $\mathrm{S}$ showed elevated concentrations in $\mathrm{PM}_{10}$ samples compared with their respective $\mathrm{RDD}_{4}$. Firstly, maybe all particle sizes of these elements are coarser, for this reason their concentrations would be higher in $\mathrm{PM}_{10}$. Moreover, the presence of airborne $\mathrm{Sb}, \mathrm{Zn}$ and $\mathrm{Mn}$ could be directly related to wear in machinery used in the underground mines. Amato et al. 2009a, b, among others, show Sb, Mn and $\mathrm{Zn}$ in atmospheric PM from abrasion sources (i.e. brake pads or tyres in vehicles) have generally a coarser size $\left(\mathrm{PM}_{2.5-10}\right)$ than resuspension. If this is the case in our studies (machinery wear sources), higher $\mathrm{PM}_{10}$ than $\mathrm{DD}_{4}$ levels might be expected for them. On the other hand, $\mathrm{Na}$ and $\mathrm{S}$ are directly related to coal handling activities because these elements are coming from their organic matter. Furthermore, a multi regression analysis was performed to correlate average $S$ content in $\mathrm{PM}_{10}$ with $\mathrm{S}$ in parent coal from each coal mine. The high correlation $\left(R^{2}=0.98, P=0.0001\right)$ indicates that $\mathrm{S}$ emissions related to $\mathrm{PM}_{10}$ ambient concentrations in the underground coal mine are directly related to coal handling and manipulation (drilling, extraction, transportation).

\section{Conclusions}

The analysis of the particle size distribution (PSD) of deposited dust (DD) finer than $500 \mu \mathrm{m}\left(\mathrm{DD}_{500}\right)$ in underground mines confirms the need to wet airborne coal dust and DD. In the Velenje Coal Basin (VCB) underground mine, $\mathrm{DD}_{500}$ is wetted which reduces the load of respirable DD (RDD), and accordingly the potential for miners to inhale coal dusts and for coal dust explosions. In contrast, in the Upper Silesian Coal Basin (USCB) underground mines, the combination of low moisture in the $\mathrm{DD}_{500}$ and a high ash yield doubles the relative load of $\mathrm{RDD}$ in $\mathrm{DD}_{500}$ when compared with VCB.

The geochemical composition of aged (collected over long time periods onto existing surfaces; sampled with a brush) and fresh (deposited on PVC trays over short time periods) DD coal samples from the same locations did not show major differences with the exception of $\mathrm{Sb}$ which was enriched in the aged DD, probably due to a relatively higher component of dust from brake-wear.

A comparison of geochemical compositions of parent coals and $\mathrm{DD}_{500}$ revealed very important differences, with relatively high levels of most major and trace elements in the $\mathrm{DD}_{500}$ for the VCB underground mine, especially for $\mathrm{Ni}, \mathrm{Zr}$ and $\mathrm{Sb}$. This can be attributed to an increased contribution to $\mathrm{DD}_{500}$ from particulate matter (PM) emitted from the wear of mine machinery (e.g. drills, excavators and blts, coal gangue, and from coal fly ash (called Malta
D) and carbonate 'rock dust' (called Calplex) commonly used as backfill and fire hazard reduction respectively in this mine. The chemical composition of RDD (deposited dust finer than 4 and $2.5 \mu \mathrm{m}, \mathrm{RDD}_{4}$ and $\mathrm{RDD}_{2.5}$ ) samples extracted in the laboratory from $\mathrm{DD}_{500}$ reveals frequent enrichments of metals and metalloids in the RDD. In the VCB mine these include $\mathrm{Ba}, \mathrm{Se}, \mathrm{Zn}, \mathrm{Pb}, \mathrm{As}, \mathrm{Cr}$, Mo, and especially $\mathrm{Ni}, \mathrm{Sn}, \mathrm{Cu}$, and $\mathrm{Sb}$.

Similar results were obtained for the USCB mines, where $\mathrm{DD}_{500}$ samples were also markedly enriched in $\mathrm{Ca}$ and $\mathrm{K}$ compared with parent coals. The enrichment in $\mathrm{Ca}$ is attributed to dusts from concrete gunite used behind mine supports, whereas $\mathrm{K}$ is attributed to dust contributions from coal gangue. An enrichment in $\mathrm{Rb}, \mathrm{Zr}, \mathrm{Sb}, \mathrm{Zn}$, $\mathrm{Cr}, \mathrm{V}, \mathrm{Ti}, \mathrm{Mn}$ and $\mathrm{Sn}$ in the $\mathrm{DD}_{500}$ compared with the parent coal was evidenced. In contrast, $\mathrm{S}$ contents were higher in the parent coals probably due to the major association of $\mathrm{S}$ with the coal matrix (reduced in DD with respect the coal seam).

The USCB mines also showed a marked enrichment in metals and metalloids in $\mathrm{RDD}_{4}$ compared with $\mathrm{DD}_{500}$, especially for $\mathrm{Cu}, \mathrm{Sn}, \mathrm{Zn}$, As and $\mathrm{Sb}$ ( $>1.5$ fold higher than in the $\mathrm{DD}_{500}$ ). In contrast, $\mathrm{Mn}$ was reduced in the $\mathrm{RDD}_{4}$ samples compared to $\mathrm{DD}_{500}$ in all samples from both VCB and USCB mines.

According to the above results, we conclude that the geochemical composition of the RDD is markedly different to that of DD and the parent coals, and that the method we have used allows extracting RDD from DD sampling for further PSD, chemical and mineralogical analyses.

Airborne $\mathrm{PM}_{10}$ concentrations were below established occupational exposure limits. Long-wall shearer excavations produce lower PM coal dust concentrations than roadway drivage operations. Higher $\mathrm{PM}_{10}$ concentrations were observed in some USCB underground mine sections related to different mechanical tasks being conducted in the mines. However, these concentration peaks were present only transiently (typically over $80-135 \mathrm{~min}$ ) and thus are not directly applicable to the $8 \mathrm{~h}$ period legislated for occupation exposure.

Concentrations of metals and metalloids in $\mathrm{PM}_{10}$ were normally lower than in the $\mathrm{RDD}_{4}$ samples, with the exception of $\mathrm{Sb}, \mathrm{Zn}, \mathrm{Mn}, \mathrm{Na}$, and $\mathrm{S}$ in some mines, that they could be present in the coarser particles. The presence of $\mathrm{Sb}, \mathrm{Zn}$, and $\mathrm{Mn}$ in $\mathrm{PM}_{10}$ may be attributed to machine wear. In contrast, $\mathrm{S}$ and $\mathrm{Na}$ may be attributed to the organic matter of coal. Moreover, S concentrations are directly correlated with coal handling manipulation in the underground coal mines $\left(R^{2}=0.98, P<0.05\right)$.

There have been few studies regarding the possible health implications of inhaling some of these metals and metalloids, further studies on the oxidative potential and cellular toxicology of coal dust samples should be carried out (Birch 
and Scollen 2003; Moreno et al. 2008; Colinet et al. 2010; Riley et al. 2012; Perret et al. 2017). Concentrations of such metals, and of coal dusts in general, should be kept at a minimum when working in underground mines. The studies carried out within the ROCD project aim to be the seed of future activities necessary to achieve better working conditions in this environment, especially given that global coal production may grow over the next few decades (BP 2020).

Supplementary Information The online version contains supplementary material available at https://doi.org/10.1007/s40789-022-00468-2.

Acknowledgements This work forms part of the "Reducing risks from Occupational exposure to Coal Dust" (ROCD) project which is supported by the European Commission Research Fund for Coal and Steel; Grant Agreement Number-754205 and the Generalitat de Catalunya (SGR41). Thanks to all partners in the ROCD project for their assistance in this study; see partner list at: http://emps.exeter.ac.uk/csm/ rocd/. IDAEA-CSIC is a Centre of Excellence Severo Ochoa (Spanish Ministry of Science and Innovation, Project CEX2018-000794-S). Malvern Mastersizer Scirocco 2000 extension measurements were performed at the ICTS NANBIOSIS by the Nanostructured Liquids Unit (U12) of the CIBER in Bioengineering, Biomaterials \& Nanomedicine (CIBER-BBN), located at the IQAC-CSIC (Barcelona, Spain).

Author's contributions The corresponding author, PT, is responsible for ensuring that the descriptions are accurate and agreed by all authors, did the analyses and most of writing. XQ and TM participated in discussed results, also wrote some sections and reviewed the manuscript. RL, DJ and AW were the responsible of sampling and distribution of samples of different mines. BW participated in discussed results and reviewed the manuscript. All authors read and approved the final manuscript.

Funding European Commission Research Fund for Coal and Steel (Grant Agreement Number - 754205). Generalitat de Catalunya (SGR41). Centre of Excellence Severo Ochoa-Spanish Ministry of Science and Innovation (Project CEX2018-000794-S).

\section{Declarations}

Conflict of interests The authors declare that they have no known competing financial interests or personal relationships that could have appeared to influence the work reported in this paper.

Open Access This article is licensed under a Creative Commons Attribution 4.0 International License, which permits use, sharing, adaptation, distribution and reproduction in any medium or format, as long as you give appropriate credit to the original author(s) and the source, provide a link to the Creative Commons licence, and indicate if changes were made. The images or other third party material in this article are included in the article's Creative Commons licence, unless indicated otherwise in a credit line to the material. If material is not included in the article's Creative Commons licence and your intended use is not permitted by statutory regulation or exceeds the permitted use, you will need to obtain permission directly from the copyright holder. To view a copy of this licence, visit http://creativecommons.org/licenses/by/4.0/.

\section{References}

Ajrash MJ, Zanganeh J, Moghtaderi B (2017) The effects of coal dust concentrations and particle sizes on the minimum auto-ignition temperature of a coal dust cloud. Fire Mater 41:908-915. https:// doi.org/10.1002/fam.2437

Amato F, Pandolfi M, Escrig A et al (2009a) Quantifying road dust resuspension in urban environment by Multilinear Engine: a comparison with PMF2. Atmos Environ 43:2770-2780. https://doi. org/10.1016/j.atmosenv.2009.02.039

Amato F, Querol X, Alastuey A et al (2009b) Evaluating urban PM10 pollution benefit induced by street cleaning activities. Atmos Environ 43:4472-4480. https://doi.org/10.1016/j.atmosenv. 2009.06.037

Azam S, Mishra DP, Wang X et al (2019) Synergistic effect of surfactant compounding on improving dust suppression in a coal mine in Erdos, China. Process Saf Environ Prot 344:35-43. https://doi.org/10.1016/j.powtec.2018.12.061

Basic Legal Act in Poland (2010) OCCUPATIONAL EXPOSURE LIMITS FOR AIRBORNE TOXIC SUBSTANCES. Basic Legal Act in Poland.

Birch GF, Scollen A (2003) Heavy metals in road dust, gully pots and parkland soils in a highly urbanised sub-catchment of Port Jackson, Australia. Aust J Soil Res 41:1329-1342. https://doi. org/10.1071/SR02147

BP (2020) bp Statistical Review of World Energy 2020

Brezigar A (1987) Geologic setting of the Pre-Pliocene basement of the Velenje depression and its surroundings. Geologija 30:31-65

Caballero-Gallardo K, Olivero-Verbel J (2016) Mice housed on coal dust-contaminated sand: a model to evaluate the impacts of coal mining on health. Toxicol Appl Pharmacol 294:11-20. https://doi. org/10.1016/j.taap.2016.01.009

Cohen RAC, Patel A, Green FHY (2008) Lung disease caused by exposure to coal mine and silica dust. Semin Respir Crit Care Med 29:651-661

Colinet JF, James PR, Jeffrey ML et al (2010) Best practices for dust control in coal mining. Centers Dis Control Prev Natl Inst Occup Saf Heal 01:17-36

Dalal NARS, Newman J, Pack D et al (1995) Original Contrib 18:11-20

EPA (1995) Reducing methane emissions from coal mines in poland: a handbook for expanding. Atmos Pollut Prev Div US Environ Prot AGENCY

Fan L, Liu S (2021) Respirable nano-particulate generations and their pathogenesis in mining workplaces: a review. Int J Coal Sci Technol. https://doi.org/10.1007/s40789-021-00412-w

Fan T, Zhou G, Wang J (2018) Preparation and characterization of a wetting-agglomeration-based hybrid coal dust suppressant. Process Saf Environ Prot 113:282-291. https://doi.org/10.1016/j. psep.2017.10.023

Fang X, Yuan L, Jiang B et al (2020) Effect of water-fog particle size on dust fall efficiency of mechanized excavation face in coal mines. J Clean Prod 254:120146. https://doi.org/10.1016/j.jclep ro.2020.120146

Hu S, Gao Y, Feng G et al (2021) Experimental study of the dustremoval performance of a wet scrubber. Int J Coal Sci Technol 8:228-239. https://doi.org/10.1007/s40789-021-00410-y

Jiang H, Luo Y (2021) Development of a roof bolter drilling control process to reduce the generation of respirable dust. Int J Coal Sci Technol 8:199-204. https://doi.org/10.1007/s40789-021-00413-9

Jiang L, Sheng C (2018) Correlation of the sub-micrometer ash yield from pulverized coal combustion with coal ash composition. Energy Fuels 32:9961-9970. https://doi.org/10.1021/acs.energ yfuels.8b02098 
Jin L, Liu J, Guo J et al (2021) Physicochemical factors affecting the wettability of copper mine blasting dust. Int J Coal Sci Technol 8:265-273. https://doi.org/10.1007/s40789-021-00411-x

Johann-Essex V, Keles C, Rezaee M et al (2017) Respirable coal mine dust characteristics in samples collected in central and northern Appalachia. Int J Coal Geol 182:85-93. https://doi.org/10.1016/j. coal.2017.09.010

Jonek-Kowalska I (2018) How do turbulent sectoral conditions sector influence the value of coal mining enterprises? Perspectives from the Central-Eastern Europe coal mining industry. Resour Policy 55:103-112. https://doi.org/10.1016/j.resourpol.2017.11.003

Kedzior S (2015) Methane contents and coal-rank variability in the Upper Silesian Coal Basin, Poland. Int J Coal Geol 139:152-164. https://doi.org/10.1016/j.coal.2014.09.009

Kędzior S (2009) Accumulation of coal-bed methane in the south-west part of the Upper Silesian Coal Basin (southern Poland). Int J Coal Geol 80:20-34. https://doi.org/10.1016/j.coal.2009.08.003

Kędzior S (2019) Distribution of methane contents and coal rank in the profiles of deep boreholes in the Upper Silesian Coal Basin, Poland. Int J Coal Geol 202:190-208. https://doi.org/10.1016/j. coal.2018.12.010

Ketris MP, Yudovich YE (2009) Estimations of clarkes for carbonaceous biolithes: world averages for trace element contents in black shales and coals. Int J Coal Geol 78:135-148. https://doi.org/10. 1016/j.coal.2009.01.002

Kotarba MJ (2001) Composition and origin of coalbed gases in the Upper Silesian and Lublin basins, Poland. Org Geochem 32:163180. https://doi.org/10.1016/S0146-6380(00)00134-0

Kotas A, Koniela Z, Wojcik A et al (1994) Coal-bed methane potential of the Upper Silesian Coal Basin. Coal-bed methane potential Up Silesian Coal Basin, Poland, p 142

Kotas A, Porzycki J (1984) Major features of Carboniferous coal basins in Poland. Przegląd Geol 32:268-280

Kuai N, Huang W, Yuan J et al (2012) Experimental investigations of coal dust-inertant mixture explosion behaviors. Procedia Eng 26:1337-1345. https://doi.org/10.1016/j.proeng.2011.11.2309

Küçük A, Kadioğlu Y, Gülaboğlu MŞ (2003) A study of spontaneous combustion characteristics of a Turkish lignite: Particle size, moisture of coal, humidity of air. Combust Flame 133:255-261. https://doi.org/10.1016/S0010-2180(02)00553-9

Kusiak MA, Kedzior A, Paszkowski M et al (2006) Provenance implications of Th-U-Pb electron microprobe ages from detrital monazite in the Carboniferous Upper Silesia Coal Basin, Poland. Lithos 88:56-71. https://doi.org/10.1016/j.lithos.2005.08.004

Leonard R, Zulfikar R, Stansbury R (2020) Coal mining and lung disease in the 21st century. Curr Opin Pulm Med 26:135-141. https:// doi.org/10.1097/MCP.0000000000000653

Li Q, Lin B, Zhao S, Dai H (2013) Surface physical properties and its effects on the wetting behaviors of respirable coal mine dust. Powder Technol 233:137-145. https://doi.org/10.1016/j.powtec. 2012.08.023

Liu G, Vassilev SV, Gao L et al (2005) Mineral and chemical composition and some trace element contents in coals and coal ashes from Huaibei coal field China. Energy Convers Manag. https://doi.org/ 10.1016/j.enconman.2004.11.002

Liu J, Wang S, Jin L et al (2021) Water-retaining properties of NCZ composite dust suppressant and its wetting ability to hydrophobic coal dust. Int J Coal Sci Technol 8:240-247. https://doi.org/10. 1007/s40789-020-00385-2

Markic M, Sachsenhofer RF (1997) Petrographic composition and depositional environments of the Pliocene Velenje lignite seam (Slovenia). Int J Coal Geol 33:229-254. https://doi.org/10.1016/ S0166-5162(96)00043-2

Markič M, Sachsenhofer RF (2010) The velenje lignite its petrology and genesis
Marts JA, Gilmore RC, Brune JF, et al (2015) Optimizing nitrogen injection for progessively sealed panels. In: 2015 SME Annual Conference Expo C 117th Natl West Min Conf - Min Navig Glob Waters $447-450$

McPherson MJ (1993) Subsurface ventilation systems. Subsurface ventilation and environmental engineering. Springer, Netherlands, pp 91-133

Moreno T, Amato F, Querol X et al (2008) Trace element fractionation processes in resuspended mineral aerosols extracted from Australian continental surface materials. Soil Res 46:128. https://doi.org/ 10.1071/SR07121

Moreno T, Trechera P, Querol X et al (2019) Trace element fractionation between PM10 and PM2.5 in coal mine dust: Implications for occupational respiratory health. Int J Coal Geol 203:52-59. https://doi.org/10.1016/j.coal.2019.01.006

Palmer AD, Cheng M, Goulet JC, Furimsky E (1990) Relation between particle size and properties of some bituminous coals. Fuel 69:183-188. https://doi.org/10.1016/0016-2361(90)90171-L

dos Pedroso-Fidelis G, S, Farias HR, Mastella GA, et al (2020) Pulmonary oxidative stress in wild bats exposed to coal dust: A model to evaluate the impact of coal mining on health. Ecotoxicol Environ Saf. https://doi.org/10.1016/j.ecoenv.2020.110211

Perret JL, Plush B, Lachapelle P et al (2017) Coal mine dust lung disease in the modern era. Respirology 22:662-670. https://doi. org/10.1111/resp.13034

Querol X, Fernandez Turiel JL, Lopez Soler A, Duran ME (1992) Trace elements in high-S subbituminous coals from the teruel Mining District, northeast Spain. Appl Geochemistry 7:547-561. https://doi.org/10.1016/0883-2927(92)90070-J

Querol X, Whateley MKG, Fernández-Turiel JL, Tuncali E (1997) Geological controls on the mineralogy and geochemistry of the Beypazari lignite, central Anatolia, Turkey. Int J Coal Geol 33:255-271. https://doi.org/10.1016/S0166-5162(96)00044-4

Reed WR, Shahan MR, Zheng Y, Mazzella A (2021) Laboratory results of foam application testing for longwall shield dust control in a simulated environment. Int J Coal Sci Technol 8:217-227. https:// doi.org/10.1007/s40789-021-00414-8

Reid DC, Hainsworth DW, Ralston JC, McPhee RJ (2006) Shearer guidance: a major advance in longwall mining. Springer Tracts Adv Robot 24:469-476. https://doi.org/10.1007/10991459_45

Riley KW, French DH, Farrell OP, Wood RA, Huggins FE (2012) Modes of occurrence of trace and minor elements in some Australian coals. Int J Coal Geol 94:214-224

Smith A 6, Diamond WP, Mucho TP, Organiscak A (1994) Bleederless ventilation systems as a spontaneous combustion control measure in U.S. coal mines United States department of the interlor

Song Z, Konietzky H, Herbst M (2020) Drawing mechanism of fractured top coal in longwall top coal caving. Int J Rock Mech Min Sci 130:104329. https://doi.org/10.1016/j.ijrmms.2020.104329

Sperazza M, Moore JN, Hendrix MS (2004) High-resolution particle size analysis of naturally occurring very fine-grained sediment through laser diffractometry. J Sediment Res 74:736-743. https:// doi.org/10.1306/031104740736

Stępniewska Z, Pytlak A, Kuźniar A (2014) Distribution of the methanotrophic bacteria in the Western part of the Upper Silesian Coal Basin (Borynia-Zofiówka and Budryk coal mines). Int J Coal Geol 130:70-78. https://doi.org/10.1016/j.coal.2014.05.003

Sunkpal M, Roghanchi P, Kocsis KC (2017) A method to protect mine workers in hot and humid environments. Saf Health Work 9:149_ 158. https://doi.org/10.1016/j.shaw.2017.06.011

Swaine DJ (1990) Trace elements in coal. Butterworth

Szkudlarek Z, Janas S (2021) Active protection of work area against explosion of dust-gas mixture. Int J Coal Sci Technol. https://doi. org/10.1007/s40789-020-00387-0 
Trechera P, Moreno T, Córdoba P et al (2020) Mineralogy, geochemistry and toxicity of size-segregated respirable deposited dust in underground coal mines. J Hazard Mater 399:122935. https://doi. org/10.1016/j.jhazmat.2020.122935

Trechera P, Moreno T, Córdoba P et al (2021) Comprehensive evaluation of potential coal mine dust emissions in an open-pit coal mine in Northwest China. Int J Coal Geol 235:103677. https://doi.org/ 10.1016/j.coal.2021.103677

Vaněk M, Bora P, Maruszewska EW, Kašparková A (2017) Benchmarking of mining companies extracting hard coal in the Upper Silesian Coal Basin. Resour Policy 53:378-383. https://doi.org/ 10.1016/j.resourpol.2017.07.010

Więckol-Ryk A, Krzemień A, Sánchez Lasheras F (2018) Assessing the breathing resistance of filtering-facepiece respirators in Polish coal mines: a survey and laboratory study. Int J Ind Ergon 68:101-109. https://doi.org/10.1016/j.ergon.2018.07. 001

Woskoboenko F (1988) Explosibility of Victorian brown coal dust. Fuel 67:1062-1068. https://doi.org/10.1016/0016-2361(88) 90371-7

Wu Q, Han L, Xu M et al (2019) Effects of occupational exposure to dust on chest radiograph, pulmonary function, blood pressure and electrocardiogram among coal miners in an eastern province. China BMC Public Health 19:1229. https://doi.org/10.1186/ s12889-019-7568-5

Yuan J, Wei W, Huang W et al (2014) Experimental investigations on the roles of moisture in coal dust explosion. J Taiwan Inst Chem Eng 45:2325-2333. https://doi.org/10.1016/j.jtice.2014.05.022

Zhang Q, Chen X, Wang H, Xu C (2021) Exploration on molecular dynamics simulation methods of microscopic wetting process for coal dust. Int J Coal Sci Technol 8:205-216. https://doi.org/10. 1007/s40789-021-00415-7

Zhang T, Jing D, Ge S et al (2020) Numerical simulation of the dimensional transformation of atomization in a supersonic aerodynamic atomization dust-removing nozzle based on transonic speed compressible flow. Int J Coal Sci Technol 7:597-610. https://doi.org/ 10.1007/s40789-020-00314-3

Publisher's Note Springer Nature remains neutral with regard to jurisdictional claims in published maps and institutional affiliations. 